Article

\title{
Field Study of Mass Balance, and Hydrology of the West Khangri Nup Glacier (Khumbu, Everest)
}

\author{
Daniele Bocchiola ${ }^{1,2, *(\mathbb{D}}$, Giovanni Martino Bombelli ${ }^{1}$, Federica Camin ${ }^{3,4}$ and \\ Paolo Maria Ossi 5 \\ 1 Politecnico di Milano Dip. Ingegneria Civile e Ambientale, L. da Vinci 32, 20133 Milano, Italy; \\ giovannimartino.bombelli@polimi.it \\ 2 Associazione EVK2CNR, San Bernardino 145, 24126 Bergamo, Italy \\ 3 Food Quality and Nutrition Department, Research and Innovation Centre, Fondazione Edmund Mach, \\ via Mach 1, 38010 San Michele all'Adige (TN), Italy; federica.camin@fmach.it \\ 4 Center Agriculture Food Environment (C3A), University of Trento, via Mach 1, \\ 38010 San Michele all'Adige (TN), Italy \\ 5 Politecnico di Milano, Dip. Energia, Ponzio 34-3, 20133 Milano, Italy; paolo.ossi@polimi.it \\ * Correspondence: daniele.bocchiola@polimi.it; Tel.: +39-02-2399-6223
}

Received: 29 November 2019; Accepted: 30 January 2020; Published: 6 February 2020

check for updates

\begin{abstract}
The depiction of glaciers' dynamics in the high altitudes of Himalaya and the hydrological fluxes therein is often limited. Although sparse seasonal (snow/ice) melt data may be available, dense precipitation networks are not available everywhere, and especially in the highest area, and the assessment of accumulation processes and mass balance may be difficult. Hydrological fluxes are little measured in the high altitudes, and few studies are available covering flow modeling and flow partitioning. Here, we investigate the snow accumulation, ice melt, and mass balance of West Khangri Nup (WKN) glacier $\left(0.23 \mathrm{~km}^{2}\right.$, mean altitude $5494 \mathrm{~m}$ asl), which is a part of the Khumbu glacier in the Everest region, where information of precipitation and hydro-glaciological dynamics in the highest altitudes was made available recently in fulfillment of several research projects. Weather, glaciological, snow pits, hydrologic, and isotopic data gathered during field campaigns (2010-2014) on the glacier and at the EVK2CNR Pyramid site were used to (i) set up the Poli-Hydro glacio-hydrological model to describe ice and snow melt and hydrological flows from the glacier, and (ii) investigate seasonal snow dynamics on this high region of the glacier. Coupling ice ablation data and Poli-Hydro simulation for ca. 5 years (January 2010-June 2014), we estimate that the WKN depleted ca. $-10.46 \mathrm{~m}$ of ice water equivalent per year $\mathrm{m}$ IWE year ${ }^{-1}$ (i.e., annually ca. -2.32 meter of water equivalent per year $\mathrm{m}$ $\left.\mathrm{WE}_{\text {year }}{ }^{-1}\right)$. Then, using snowpack density and isotopic $\left(\delta^{18} O\right)$ profiles on the WKN, we demonstrate that the local snowpack is recent (Fall-Winter 2013-2014) and that significant snow accumulation did not occur recently, so this area has not been a significant one of accumulation recently. Analysis of recent snow cover from LANDSAT images also confirms snow dynamics as depicted. Our study presents original data and results, and it complements present studies covering glaciers' mass balance as well as an investigation of accumulation zones in the Everest region and the Himalayas, which is also potentially helpful in the assessment of future dynamics under ongoing climate change.
\end{abstract}

Keywords: Himalayan water towers; climate change; glaciers' evolution; mass balance

\section{Introduction}

Evidence of global change as set out by the last assessment reports of the International Panel on Climate Change (IPCC) [1,2] indicates a large present and expected impact on the highest altitude areas. Future snow and ice cover worldwide are projected to shrink down, and water resources will be largely modified therein [3-11]. 
Hindu Kush, Karakorum, and Himalaya (HKKH) host large glaciers that in the last 50 years underwent climate change, subsequent shrinking, and large increase of debris coverage [12-21].

Information about glaciers in these remote regions is often based on satellite data, which routinely document the retreat or advance of ice-covered areas [22,23], while volume changes are less easy to quantify [24] and often require local assessment [25]. Estimation of mass balance also requires local information. Air temperature (and maybe solar radiation) is (are) necessary to estimate ablation [26], and precipitation provides accumulation estimates $[27,28]$ for mass balance. Air temperature shows greater variation with altitude than horizontally, and vertical lapse rates can be used, while precipitation is more erratic and can change within short distances, and with altitude [6,8,29]. Further, snowfall should be separated from rainfall. Long-term weather measurements in the highest glacierized areas are seldom available $[8,30]$, and an assessment of hydro-climatic trends is possible only at relatively low altitudes [31].

Uncertainty in the assessment of glaciers' mass balance in the Himalayas may result from the lack of in situ high-altitude precipitation (and snowfall in the accumulation areas) assessment [8], which is often tackled with proxies, such as lapse rate-based interpolation [29], gridded products (e.g., APHRODITE [32]), remote sensing estimates [21,33], and even "reverse hydrology" exercises [34-36]. In less monitored areas, scarce knowledge of precipitation regime in the high altitude may further hamper hydrological modeling and water budget closure [37].

In addition, rarely available high altitude hydrological measurements may complement mass balance assessment and hydrological conjectures [6,8,38], otherwise requiring some ad hoc and at times questionable hypotheses on stream flow dynamics [39].

Among others, snowpack sampling, including isotopic profiling [24,40,41], is a valuable tool for the purpose of estimating potential mass inputs on high altitude glaciers. Stable isotope ratios of oxygen $\left({ }^{18} \mathrm{O} /{ }^{16} \mathrm{O}\right.$, expressed as $\left.\delta^{18} \mathrm{O}\right)$ in precipitation relate to air temperature at water vapor condensation [42], so the value of $\delta^{18} \mathrm{O}$ in snow or ice is a good proxy for air temperature variations in time, and the reconstruction of seasonal temperature variations may help in establishing the timeline of snow deposition.

In Nepal, agriculture practiced by $90 \%$ of the active population is highly water dependent, and there is a large need of adaptation in water allocation strategies against climate change, even at high altitudes [43-47]. Moreover, the use of water for small run of river hydropower plants, albeit low in percentage (about $3 \%$ of total energy production) is increasing [48,49], and may indeed be impacted by forthcoming water shortage [50]. Accordingly, accurate knowledge of present and perspective cryospheric fate and hydrology is necessary.

In this study, we investigated the state of the bare West Khangri Nup (WKN) glacier [51,52], which is a representative ice body in the Everest region, to increase knowledge of the glaciers' condition in this area and the Himalayas in general. Recently in this area, continued investigation of weather (e.g., [31]), and glacio-hydrological dynamics (e.g., [8,37]) provided important data for the investigation of climate-driven mass balance in the high altitudes, on which we rely here.

To do so, we exploited data from field campaigns (2010-2014), high altitude in situ weather and hydrological data, and glacio-hydrological modeling to investigate the snow accumulation, ice melt, mass balance, and hydrology of the WKN glacier $\left(0.23 \mathrm{~km}^{2}\right.$, mean altitude $5494 \mathrm{~m}$ asl), covering the northwest part of the Khumbu glacier in the Everest region. West Khangri Nup glacier is representative of bare, high-altitude Himalayan glaciers, and it is nested within the Dudh Koshi (milk river) basin of Nepal, at the toe of Mt. Everest. The glaciers therein have experienced a negative mass balance in the last three decades $[8,18,53,54]$, and accordingly, investigation of their recent and prospective dynamics is warranted [55]. We could build here upon unexploited data from recent field campaigns that provide information of glacial dynamics of the West Khangri Nup glacier, namely (i) hydrological fluxes at a flow station capturing flows from a part of the WKN during 2012-2013 (5332 m asl), (ii) ice and snow melt and depth at 12 stakes (on bare ice, 5402-5601 m asl) measured during 2010-2014, (iii) snow pit data (5601 $\mathrm{m}$ asl), including snow depth, density, and isotopic values $\left(\delta^{18} O\right)$ in 2014 , and 
(iv) weather data at two EVK2CNR stations (Pyramid, $5050 \mathrm{~m}$ asl; Khangri Nup, $5601 \mathrm{~m}$ asl). The data gathered were used to (i) set up the Poli-Hydro glacio-hydrological model able to describe ice and snow melt, glacier mass balance, and hydrological flows from the glacier, and (ii) investigate seasonal snow dynamics on this high, possibly accumulation zone.

The present results come from activities carried out within the SHARE-Paprika project (2010-2013) and the Khumbu Hydrology project (2014-2015), which were funded by the EVK2CNR committee of Italy, managing the Nepal Climate Observatory-Pyramid in the Khumbu valley [56].

The manuscript is organized as follows. In the "Case study area" section, we describe the West Khangri Nup glacier, and climate therein. In the "Database" section, we describe the database, including historical weather data, and newly gathered hydrological, glaciological, and isotopic data, while in the "Methods" section, we report on the methodology and models used here. In the "Results" section, we provide the outputs of our modeling effort. In the "Discussion" section, we benchmark our results against available studies in the literature, we deepen into the present, and possibly future behavior of the West Khangri Nup glaciers, and we highlight the limitations of the study as well as future outlooks. Then, we draw some conclusions, and we outline possible future efforts.

\section{Case Study Area}

The WKN glacier (Figure 1) covers the south part of Khangri glacier, nested in the west part of the Khumbu, on the southern slopes of Mt. Everest, which ranges from 5330 to $5838 \mathrm{~m}$ asl $\left(1.06 \mathrm{~km}^{2}\right.$ in area). The glacier is part of the Sagarmatha (Everest) National Park SNP, which is the world's highest protected area; it is visited every year by tourists and climbers to Everest and other peaks [57-59]. While the Khumbu and Khangri glaciers are heavily debris covered, the West Khangri Nup is debris free. This glacier is a relatively well-studied one, and it is somewhat representative of debris-free glaciers in the Everest area; given the relatively easy access from the Pyramid site nearby, it was possible to carry out a number of seasonal surveys therein.

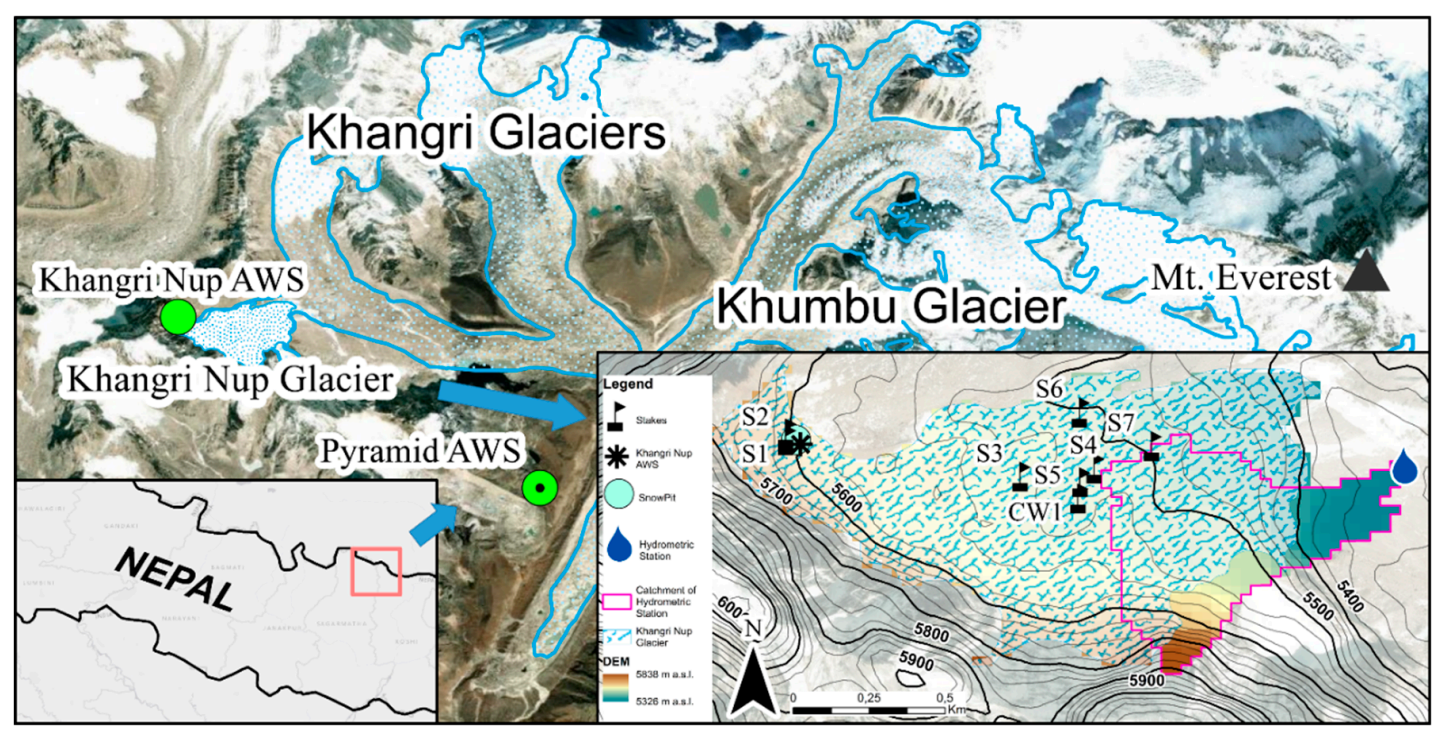

Figure 1. Case study area. West Khangri Nup glacier, Sagarmatha National Park, Nepal. The hydro-meteorological stations set up and used for this study are reported. We also report the position of the ice/snow ablation stakes and the results of snow pit survey carried out during the field campaigns (2010-2014, see also Tables 1 and 2). The contributing area at the hydrometric station is also reported.

The glaciers in the area, and the WKN, are identified as the temperate summer-accumulation type, mostly fed by summer precipitation, i.e., the South Asian monsoon [18,60]. Bolch et al. [53] assessed the mass balance of Khumbu and Khangri glaciers (1970-2007), nearby -0.28 and $-0.27 \mathrm{~m}$ of water 
equivalent per year $\mathrm{m} \mathrm{WE}$ year $^{-1}$, respectively, with a lowering of debris surface of the Khumbu glacier of ca. $-0.38 \mathrm{~m} \mathrm{WE}$ year $^{-1}$, similarly to average mass loss of the 30 reference glaciers worldwide during 1976-2005 (-0.32 m WE year ${ }^{-1}$, [61]). Thakuri et al. [18] estimated glaciers' area loss in SNP since the early 1960s, with Khumbu and Khangri having lost $-6.5 \%$, and $-7.5 \%$, respectively. Li et al. [23] used five pairs of X-band bistatic TerraSAR-X/TanDEM-X images during 2011-2012 to assess glaciers' depth changes in the Mount Everest region, finding on average $-0.38 \pm 0.04 \mathrm{~m}$ ice water equivalent per year $\mathrm{m}$ IWE year ${ }^{-1}$ (ice water equivalent per year), however heterogeneously distributed. WKN here lost nearby $-1 \mathrm{~m}^{\mathrm{IWE}}$ year $^{-1}$ (Figure 7 in [23]).

The climate zone at this altitude is Polar Tundra (ET $[62,63])$, with dry/cold winters, warm summers, and monsoonal precipitation mostly. Four seasons may be identified for precipitation $[64,65]$. The pre-monsoon season (March to May) displays dry weather, high temperatures, and limited cloud cover. Monsoon onsets in June, and rainfall occurs almost every day, with $90 \%$ of annual rainfall occurring in June to September [31]. In the post-monsoon season (October to November), rainfall is scarce. Winter (December to February) is generally dry, with occasional precipitation $[33,66]$. The annual precipitation at the Pyramid station ( $5035 \mathrm{~m}$ asl, $4 \mathrm{~km}$ southeast of the glacier) averages $446 \mathrm{~mm}_{\text {year }}{ }^{-1}$, with a mean annual temperature of $-2.45^{\circ} \mathrm{C}$ [31]. In spring before monsoon, snow thaw starts, and to a lesser extent, ice melt starts as well. Ablation peaks are during the summer (monsoon) season, and a large share of summer flows is expected to derive from ice and snow melt, with snowfall at the highest altitudes providing possibly positive mass balance (i.e., accumulation). After the monsoon, river flow slowly decreases, with little snow/ice melting still occurring, and the least flows are observed during winter.

\section{Database}

\subsection{Topographic and Meteorological Data}

As a topographic layer for simulations, we used the ASTER GDEM, Vers. 2 tiles for the Khumbu area (https://asterweb.jpl.nasa.gov/gdem.asp), with a vertical and horizontal accuracy of approximately $17 \mathrm{~m}$ and $30 \mathrm{~m}$, respectively.

Meteorological information for Poli-Hydro model setup was gathered from two automatic weather stations (AWSs reported in Table 1), namely Pyramid Station (5035 m asl) and Khangri Nup (5601 m asl), which are property of the EVK2CNR committee. These stations provide measurements of temperature $T$, precipitation $P$ (Pyramid only), solar radiation $R$, and snow depth $H S$ (Pyramid only). In addition, fresh snow density $\rho_{n}$ was measured at Pyramid AWS in May-June 2014. We used the so-obtained values of $\rho_{n}$ to estimate new snow density here.

Table 1. Data available. $T$ is temperature, $P$ is precipitation, $S$ is snow height, $R$ solar radiation, $Q$ is flow rate, $M_{i}$ is ice melt, $M_{s}$ is snow melt, $\rho_{s}$ is snowpack density, and $\rho_{n}$ is new snow density, measured during May-June 2014. AWS: automatic weather stations.

\begin{tabular}{ccccccc}
\hline Station. & Variable & Alt $(\mathbf{m}$ asl) & Lat $\left({ }^{\circ} \mathbf{N}\right)$ & Lon $\left({ }^{\circ}\right.$ E) & Resolution & Period \\
\hline AWS Khangri Nup & $T, R$ & 5601 & 86.7647 & 27.9819 & hourly & $2010-2014$ \\
AWS Pyramid & $T, R, P, H S, \rho_{n}$ & 5035 & 86.8132 & 27.9590 & hourly & $2010-2014\left(\rho_{n} \mathrm{MJ} 2014\right)$ \\
Khangri hydro & $Q$ & 5332 & 86.7832 & 27.9781 & hourly & $2012-2013$ \\
Snow pit & $H S, \rho_{S}, \delta^{18} \mathrm{O}$ & 5601 & 27.9819 & 86.7647 & one day & $4 \mathrm{May} 2014$ \\
Stakes & $M_{S}, M_{i}, S$ & $5402-5601$ & - & - & various & $2010-2014$ \\
\hline
\end{tabular}

\subsection{Field Data of Ice and Snow Ablation, Snow Accumulation, and Isotopic Content}

During the period 2010-2014, some field surveys were performed in fulfillment of the SHARE-Paprika and SHARE-Dudh Koshi River projects upon the Khangri and Khumbu glacier $[8,21,67]$, including on the West Khangri Nup. Ice melt and snow melt/depth were measured at seven positions, using plastic and bamboo sticks (hereon, ice/snow stakes). The full detail of the stakes and chronology of measurements is reported in Table 2 . 
Table 2. Detail of snow and ice stakes on the West Khangri Nup glacier, 2010-2014. $M_{i}$ is ice melt, $M_{S}$ is snow melt, HS is snowpack depth.

\begin{tabular}{cccccc}
\hline Stakes & Variable & Period & Altitude $(\mathbf{m}$ asl) & Lat $\left({ }^{\circ} \mathbf{N}\right)$ & Long $\left({ }^{\circ} \mathbf{E}\right)$ \\
\hline S1 & $M_{S}$ & April-August 2010 & 5601 & 27.9820 & 86.7645 \\
S2 & $M_{S}$ & April-August 2010 & 5601 & 27.9820 & 86.7645 \\
S3 & $M_{S}$ & April-August 2010 & 5498 & 27.9808 & 86.7715 \\
S5 & $M_{S}$ & May-November 2012 & 5493 & 27.9805 & 86.7736 \\
S6 & $M_{S}$ & May-November 2012 & 5462 & 27.9827 & 86.7733 \\
S7 & $M_{S}$ & May-November 2012 & 5443 & 27.9817 & 86.7754 \\
S3 & $M_{i}$ & May-November 2012 & 5498 & 27.9808 & 86.7715 \\
S5 & $M_{i}$ & May-November 2012 & 5493 & 27.9805 & 86.7736 \\
S6 & $M_{i}$ & May-November 2012 & 5462 & 27.9827 & 86.7733 \\
S7 & $M_{i}$ & May-November 2012 & 5443 & 27.9817 & 86.7754 \\
CW1 & $M_{i}$ & May-November 2012 & 5402 & 27.9806 & 86.7733 \\
CW1 & $H S$ & 4 May 2014 & 5402 & 27.9806 & 86.7733 \\
\hline
\end{tabular}

In addition, a snow pit was performed on the western, expectedly accumulation area of the West Khangri Nup, near the EVK2-CNR weather station (5601 m asl, 4 May 2014, Figure 1). The snow pit was $1.70 \mathrm{~m}$ deep, and we reached ice underneath; snow cores were taken approximately every $15 \mathrm{~cm}$ (avoiding few small ice lenses, for a total of 11 points) to estimate snow density $\rho_{s}$ and snow water equivalent $S W E$. In the same snow pit, we measured $\delta^{18} O$ in melted snow for the same measured snow profile (11 measurements, each repeated twice, 22 samples overall). Snow samples were taken with a horizontal snow sampler (ca. $6 \mathrm{~cm}$ in diameter) for snow density assessment. For isotopic measurements, snow samples were taken using a cylindrical sampler (ca. $2.5 \mathrm{~cm}$ diameter, ca. $50 \mathrm{~cm}^{3}$ volume) and hermetically sealed with screw caps for subsequent analysis.

After the period of investigation reported here (January 2010-June 2014), other surveys were carried out in the area, focusing mostly on measuring of ice melt on the Khumbu glacier on debris-covered areas, where a number of stakes were positioned during May 2014, and subsequently monitored (see [8], where the position, measurement period, and ice melt for these stakes are reported fully). Stake CW1 reported here for the year 2014 (gray square in Figure 2 below, snow depth measured in May 2014) is the same stake as that reported in Soncini et al. ([8], Figure 1, CW1), where ice melt was measured subsequently (May-October 2014, not reported here). Otherwise, the measurements reported here cover a different period and refer to a different set of ice stakes than in [8].

\subsection{Hydrometric Station}

The discharge outlet of (part of) the West Khangri Nup glaciers was measured using a hydrometric station, placed at $5332 \mathrm{~m}$ asl, installed in May 2012 (Figure 1) within the framework of the SHARE-Paprika, which was specifically designed to quantify the glacier's outlet from this very high-altitude area. The station comprised of a (triangular) weir, built by carving a plastic (expedition) drum, equipped with a piezometric pressure gage, measuring the weir water table every $15 \mathrm{~min}$. Using salt tracer measurements carried out during May 2012, and weir geometry, an outflow curve was calibrated that was able to provide discharge flow estimation. The hydrometric station was placed ca. $300 \mathrm{~m}$ east of the WKN, to capture outflow from the southeastern part of the glacier. Given the topography of the area, it was deemed unfeasible to capture flow from the whole glacier, if not moving much downstream, thereby including flows from a much larger catchment (and other glaciers) and thus missing the target of specifically capturing the outlet of the WKN glacier.

The contributing catchment (in Figure 1) was measured with an in situ walking survey using a portable GPS and subsequently validated using the available DEM; it comprises ca. $0.35 \mathrm{~km}^{2}$, of which ca. $0.23 \mathrm{~km}^{2}$ of ice. 


\section{Methods}

\subsection{Poli-Hydro Model}

To simulate the mass balance and hydrological outlet from the WKN glacier, we used here the Poli-Hydro model, a physically based, semi-distributed glacio-hydrological model that was already validated previously $[7,68]$ and able to reproduce a hydrological cycle in high-altitude areas as shown here. The model, and the underlying approach to mimic the hydrological cycle within high-altitude, topographically complex catchments is described well elsewhere (e.g., [68]), and we only provide here a broad description. Poli-Hydro tracks the water budget into soil between two consecutive periods (here, hourly simulation is pursued), taking as input liquid precipitation (rainfall) $R$, and ice/snow melt, $M_{i} / M_{s}$. The latter are calculated using a hybrid degree day model (already adopted in the area, see [8]), considering temperature $T$ and (locally measured, spatially topographically corrected) solar radiation $R$. Given the high altitude, lack of vegetation, and shallow soils here, and after a preliminary analysis, evapotranspiration from soil was neglected (e.g., [3]). Hydrological flows occur according to two mechanisms, namely sub-superficial/groundwater flow and overland flow, the latter occurring after soil saturation. The flow discharges from each cell (30 m resolution) of the model are routed to the outlet section through a semi-distributed flow routing algorithm based on an instantaneous unit hydrograph (IUH) [69]. The model uses two systems (groundwater, overland) of linear reservoirs in series $\left(n_{g}\right.$ and $\left.n_{s}\right)$. Each of such reservoirs possesses a time constant, or lag time (i.e., $\left.l_{g}, l_{s}\right)$, to be tuned against flow data. Tuning of the Poli-hydro model parameters was pursued against observed flow data from the WKN hydro station during 2012 (calibration) and 2013 (validation).

\subsection{Ice and Snow Ablation, and Accumulation}

Ablation as modeled here depends upon temperature and solar radiation, while accumulation clearly depends upon precipitation. Temperature data (hourly scale) were taken from the WKN station and spatially distributed according to a lapse rate [8]. However, the vertical extent of the glacier is roughly $200 \mathrm{~m}$, limiting $T$ variation. Radiation data (hourly) came from the WKN station, and they were topographically distributed on the glacier by accounting for shading.

Precipitation data (hourly) were taken from the Pyramid station, and no lapse rate was applied, again given very little vertical jump to the glacier and substantially unchanged precipitation in the area above $5000 \mathrm{~m}$ asl or so [31].

The ablation of (bare) ice and snow was modeled with a mixed (radiation plus temperature) degree-day approach (as done e.g., in [26]), namely

$$
M_{i, s}=T M F_{i, s}\left(T-T_{t h}\right)+R M F_{i, s}\left(1-a_{i, s}\right) R \text { if } T \geq T_{t h} ; M_{i, s}=0 \text { if } T<T_{t h}
$$

Therein, $M_{i, s}\left(\mathrm{mmh}^{-1}\right)$ is the melting of either ice or snow within a cell, while $T M F_{i, s}\left(\mathrm{mmh}^{-1}{ }^{\circ} \mathrm{C}^{-1}\right)$ and $R M F_{i, s}\left(\mathrm{mmh}^{-1} \mathrm{~W}^{-1} \mathrm{~m}^{2}\right)$ are the temperature and radiation melt factors for either ice or snow, $a_{i, s}$ (.) is the ice/snow albedo. The albedo for clean ice and snow was set to 0.26 , and 0.75 , as from Vuillermoz et al. [70]. $T_{t h}$ is an air temperature threshold $\left(-5^{\circ} \mathrm{C}\right.$ here as from data analysis, see [71]). The snow height (HS) data collected at Pyramid during 2003-2012 were used to initially calibrate the snow melt factors, $T M F_{s}$ and $R M F_{s}$. Subsequently, the values of these parameters were slightly adjusted by the simulation of snow melt with Poli-Hydro at the (closest cell to the) snow melt stakes (S1-S7) for the measured periods (i.e., 2012, Table 2).

Ice melt parameters $T M F_{i}$ and $R M F_{i}$ were tuned by iteratively running the Poli-Hydro model to obtain an optimal fitting of modeled ice melt to observations at the (closest cell to) stakes (S3-S7, CW1) in the measured periods (i.e., 2010 and 2012, Table 2). Initial values were set taking the results of Soncini et al. [8]. Snow depth data taken during 2014 at stations Khangri and CW1 were used for validation of the snow melt module. 
Snow accumulation was simulated by snow deposition (according to snow precipitation), and subsequent settling according to Martinec's [72] approach, i.e., with snow settling driven by a power law with exponent $m$ [68]. The $m$ exponent was assessed by simulating snow compaction (i.e., dynamics of $H S$ in time, in the absence of snow melting) at the Pyramid station. Daily snowfall was converted into a water equivalent using fresh snow density measured at Pyramid during May-June 2014 as reported (on average, $\rho_{n}=180 \mathrm{~kg} \mathrm{~m}^{-3}$ ). Given the topographic setting of the glacier, covering a relatively flat area, avalanche feeding is not largely affecting ice cover, so the Poli-Hydro avalanche module $[6,8]$ was disabled. The Poli-Hydro model can use a Poli-Ice module that is able to track the ice flow velocity and ice area/volume changes over long periods. Here, given the short period of simulation of interest, we did not simulate ice flow. Soncini et al. [8] used measured superficial velocities from a number of stakes on the Khumbu basin to calibrate the Poli-Ice module, and they reported for the West Khangri Nup an estimated flow velocity of ca. $V_{i c e}=15 \mathrm{~m}_{\text {year }}{ }^{-1} \mathrm{ca}$. (Figure $4 \mathrm{c}$ in [8]). Accordingly, given the short period of simulation here (ca. 4 years), movements would be estimated in the order of ca. $60 \mathrm{~m}$ or so, which is comparable with pixels' size, and likely scarcely significant. In addition, given that we were mostly interested here in the mass balance and hydrology of the WKN, we would not enable the ice flow module. Much for the same reason, we did not consider snow to ice transition, requiring a longer period than our simulation here (i.e., 5-10 years or more, see [73]).

We pursued the Poli-Hydro simulation of WKN snow during 2010-2014 (until June). Initial conditions of snow cover on the WKN were set according to the results of Soncini et al. [8].

\section{3. $\delta^{18} \mathrm{O}$ Isotopes}

The ${ }^{18} \mathrm{O} /{ }^{16} \mathrm{O}$ ratio of melted snow was determined after the equilibration of water with $\mathrm{CO}_{2}$ with a known content of ${ }^{18} \mathrm{O}\left(\mathrm{C}^{16} \mathrm{O}_{2}+\mathrm{H}_{2}{ }^{18} \mathrm{O}=\mathrm{C}^{16} \mathrm{O}^{18} \mathrm{O}+\mathrm{H}_{2}{ }^{16} \mathrm{O}\right)$ using an isotope ratio mass spectrometer (Isoprime, Manchester, UK) interfaced with an on-line automatic system that allows $\mathrm{CO}_{2} / \mathrm{H}_{2} \mathrm{O}$ equilibration (Multiflow, Isoprime, Manchester, UK), as described e.g., by Epstein and Mayeda [74]. The ${ }^{18} \mathrm{O} /{ }^{16} \mathrm{O}$ ratio was expressed as delta per thousand $\left(\delta^{18} \mathrm{O} \%\right.$ o $)$ as the deviation of the isotope ratio of the sample from the international reference standard (i.e., Vienna Standard Mean Ocean Water, IAEA-International Atomic Energy Agency, Vienna, Austria) on a scale normalized by assigning the consensus value of $-55.5 \%$ o to SLAP (Standard Light Antarctic Precipitation, water, IAEA). Analytical uncertainty (1 standard deviation) of $\delta^{18} O$ values was $<0.2 \%$.

\section{Results}

\subsection{Ice and Snow Ablation}

Figure 2 reports the results of our snow/ice melt simulation exercise, namely the simulated values of $M_{i, s}$ and $H S$ at our stakes for specific periods, in a scatter plot format. Figure 3 displays simulation of the snowpack (HS) at the (cell containing the) EVK2CNR WKN weather station, at $5601 \mathrm{~m}$ asl, during 2010-2014 (until 30 June). Therein reported are precipitation, with partition between snow and liquid phase, temperature, and simulated snow depth, and snow water equivalent SWE. Table 3 reports the ablation model parameters (Equation (1)). For ice, model calibration is carried out according to the procedure explained in Section 4.2, i.e., running the Poli-Hydro model, to best match ice melt at some stakes during 2012. Given the few points available (i.e., 5 cumulated ice melt values in 2012), we pursued calibration only based upon the minimization of the Bias\% (i.e., percentage error in mean values estimation, reported in Table 4). Given the relatively small vertical extent of the stakes over the glacier (5402-5498 $\mathrm{m}$ asl) and of the glacier itself (5330-5601 $\mathrm{m}$ asl), we assumed that a small as possible mean error indicates on average an acceptable depiction of the melt process over the glaciers' area.

The two parameters assessed are $R M F_{i}=0.005 \mathrm{mmh}^{-1} \mathrm{~W}^{-1} \mathrm{~m}^{2}$, and $T M F_{i}=0.006 \mathrm{~mm} \mathrm{~h}^{-1}{ }^{\circ} \mathrm{C}^{-1}$. Bias $\%$ is $-2.4 \%$ for calibration. Similar to ice melt, calibration of the snow melt model was carried out by Bias\% minimization against the observed $M_{s}$, and we obtained $R M F_{s}=0.007 \mathrm{~mm} \mathrm{~h}^{-1} \mathrm{~W}^{-1} \mathrm{~m}^{2}$ and $T M F_{s}=0.05 \mathrm{~mm} \mathrm{~h}^{-1}{ }^{\circ} \mathrm{C}^{-1}$. Then, validation of the snow melt module was completed by comparing 
the HS values simulated at the WKN station against those observed in May 2014, i.e., when the snow pit was dug, and snow depth was duly measured. We obtained Bias $\%=-3.71 /+11.94 \%$ in calibration and validation (on snow depth $H S$ ), respectively. In Table 4, we report the adaptation statistics for ice and snow melt in calibration and validation. Namely, we provide (i) mean estimation error, or percentage bias Bias\%, which indicates the accuracy in estimation of the mean value (i.e., in assessment of water volume), (ii) NSE (Nash-Sutcliffe efficiency), giving the degree of explained variance of the process (ranging between $0-1$ ), and (iii) RMSE (random mean square error) in mm WE, giving an idea of the magnitude of the noise in estimation. We also report in Table 4 the results of a mixed validation exercise, i.e., by combining ice melt and snow melt, or in other words, the total available melting water.

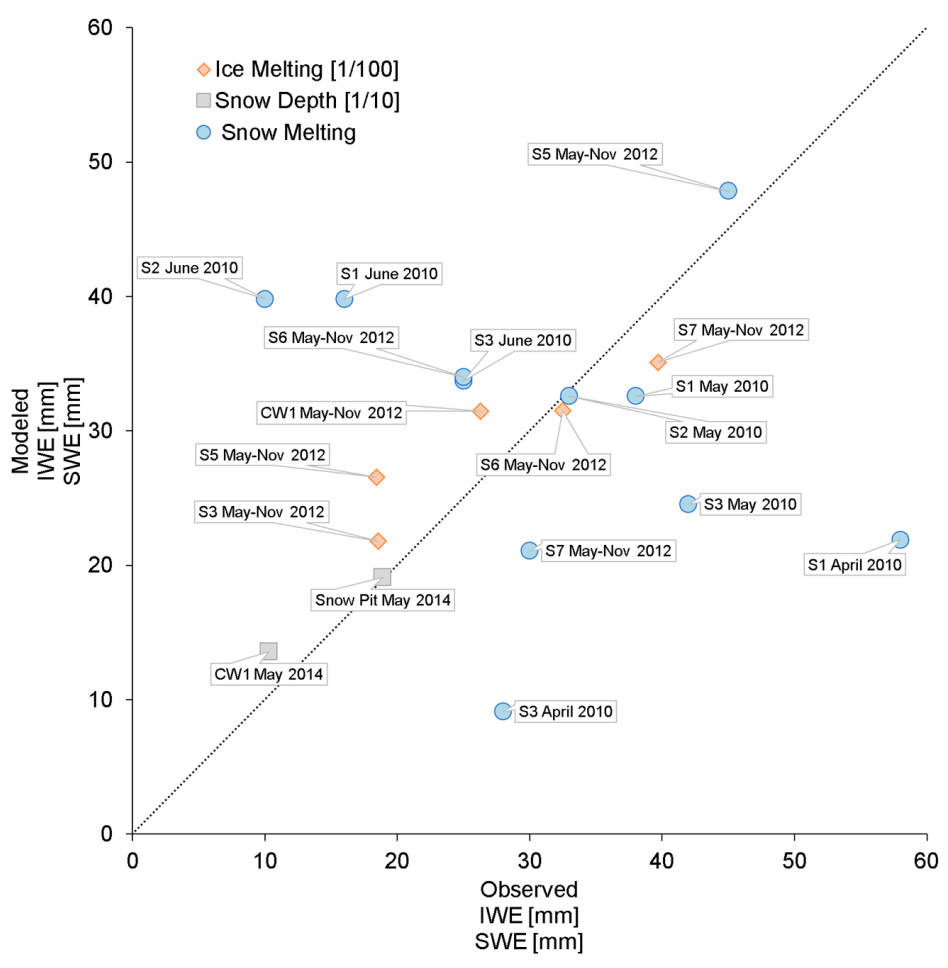

Figure 2. West Khangri Nup. Ice and snow ablation model. Goodness of fit of the modeled values at the measuring stakes. IWE is ice water equivalent, or ice melt $M_{i}$. SWE is snow water equivalent, or snow melt $M_{i}$. Snow depth is used in some cases for validation. For each stake, the measurement period is reported. Different periods for each stake indicate readings at different dates. Snow depth values to be multiplied by $10(1=10 \mathrm{~mm})$. Ice melt data to be multiplied by $100(1=100 \mathrm{~mm})$.

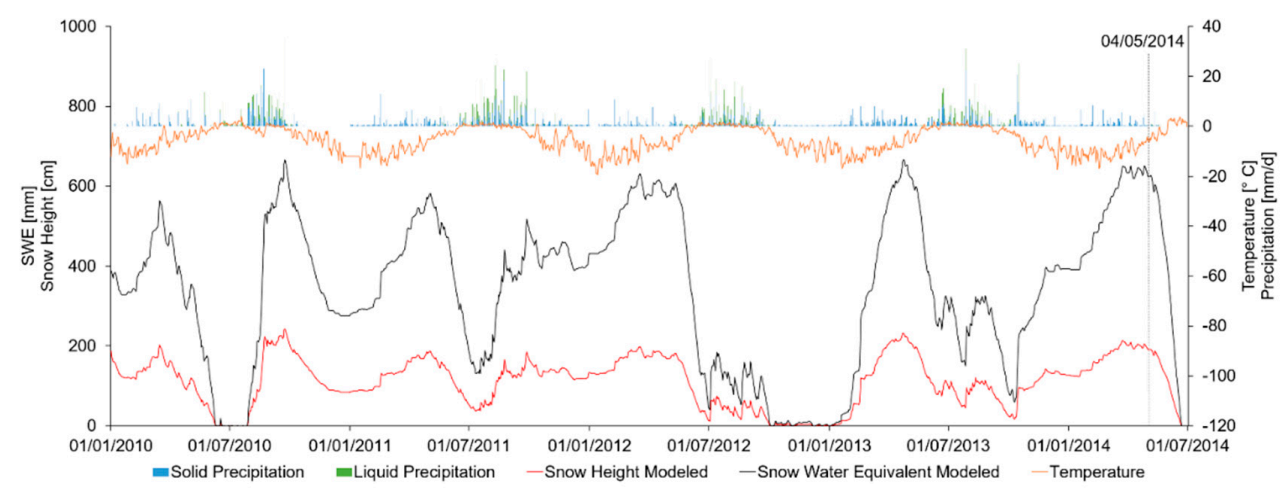

Figure 3. AWS West Khangri Nup. Snowpack simulation at EVK2CNR AWS station (5601 m asl) during 2010-2014 (30 June). Upper part. Air temperature, partition between solid and liquid precipitation reported. Lower part. Simulated snow depth and snow water equivalent. 
Table 3. Poli-Hydro model parameters, calibration methods, and values.

\begin{tabular}{cccc}
\hline Parameter & Description & Calibration Method & Value \\
\hline$T M F_{S}\left(\mathrm{~mm}^{\circ} \mathrm{C}^{-1} \mathrm{~h}^{-1}\right)$ & Thermal melt factor snow & Snow depth/SWE data & 0.05 \\
$R M F_{S}\left(\mathrm{~mm}\left(\mathrm{~W} / \mathrm{m}^{2}\right)^{-1} \mathrm{~h}^{-1}\right)$ & Radiation melt factor snow & Snow depth/SWE data & 0.007 \\
$T M F_{I}\left(\mathrm{~mm}{ }^{\circ} \mathrm{C}^{-1} \mathrm{~h}^{-1}\right)$ & Thermal melt factor clean ice & Ice melt data & 0.05 \\
$R M F_{I}\left(\mathrm{~mm}\left(\mathrm{~W} / \mathrm{m}^{2}\right)^{-1} \mathrm{~h}^{-1}\right)$ & Radiation melt factor clean ice & Ice melt data & 0.006 \\
$T_{t h}\left({ }^{\circ} \mathrm{C}\right)$ & Threshold temperature for snow/ice melting & Snow/Ice melt data & -5 \\
$M()$. & Snow compaction exponent & Snow depth & 0.15 \\
$K\left(\mathrm{~mm} \mathrm{day}^{-1}\right)$ & Saturated conductivity & Stream flow data & 4 \\
$K()$. & Ground flow exponent & Stream flow data & 3 \\
$n_{s}()$. & Reservoirs overland & Literature & 4 \\
$n_{g}()$. & Reservoirs ground & Siterature & 3 \\
$l_{t s}(\mathrm{~h})$ & Reservoir overland & Stream flow data & 12 \\
$l_{t g}(\mathrm{~h})$ & Reservoir ground & 20 \\
$\alpha_{i c e}()$. & Albedo ice & Ref. [69] & 0.26 \\
$\alpha_{\text {snow }}()$. & Albedo snow & Ref. [69] & 0.75 \\
\hline
\end{tabular}

Figure 3 displays snowpack dynamics along our 5 years (until June 2014). In three years out of five $(2010,2012,2014)$ during summer, snowpack was entirely depleted, i.e., no accumulation seemingly occurred at the station at $5601 \mathrm{~m}$ asl. This is confirmed possibly by the considerable ice melt as measured on the same stakes. For instance, at stake S6 (5462 m asl), ca. $25 \mathrm{~mm}$ of $M_{s}$ were observed during May-November 2012, with an observed cumulated ice melting $M_{i}$ during the same period of ca. $3000 \mathrm{~mm}$ (i.e., $3 \mathrm{~m}$ ), likely indicating a lack of snow cover, leading to considerable ice melt. Similarly, for stake S7 (5498 m asl), one has ca. $M_{s}=30 \mathrm{~mm}$ during May-November 2012, with an observed cumulated $M_{i}$ in that period of ca. $4000 \mathrm{~mm}$ (i.e., $4 \mathrm{~m}$ ) of ice melt. This is mirrored in Figure 3, where HS and SWE during summer-fall 2012 decrease largely, especially toward September and October.

\subsection{Hydrological Fluxes}

Figure 4 reports the results of Poli-Hydro, in terms of hydrological modeling, at the daily scale (we aggregated here hourly values for better readability), during the simulation period (2010-June 2014). The hydrometric station data were periodically downloaded by personnel of the Pyramid lab, which we kindly acknowledge, and the readings were acceptable during summer 2012, with subsequent freezing, and during most 2013. Occasionally, very high or very low values were provided at the original 15-minute resolution, which we discarded. Given the high altitude and complex geometric setting of the station, the estimated flows seemed reasonable. After winter 2013, the station would not work anymore, and measurements were discontinued. We decide to use the data for calibration (2012) and validation (2013), and we could use here several observations, so we calculated standard objective scores, such as Bias\% and NSE (see [7] for a discussion on the use of such metrics for high-altitude catchments). In Table 4, these scores are reported for the different time resolutions (hourly, daily, monthly). At the daily scale, more significant for hydrological assessment, Bias $\%$ is $+0.85 \%$ and $-11.90 \%$ for calibration and validation, and NSE is 0.456 and 0.466 , respectively, and increasing monthly (Table 4). The acceptably low bias in flow simulation seemingly indicates that overall (in one year), the amount of simulated melt is acceptably matching the observed flows in the hydro station.

The measured total precipitation at the Pyramid site was $209.3 \mathrm{~mm}$ on average (2010-2014) in the dry season (JFMAM+OND), and $431.8 \mathrm{~mm}$ on average (2010-2013) in the monsoon season (JJAS), i.e., with a share of ca. $65 \%$ of the yearly precipitation $\left(662.4 \mathrm{~mm}\right.$ year $\left.^{-1}, 2010-2013\right)$ falling during monsoonal summer, and runoff as modeled here is consistent thereby.

Figure 4 also reports the contribution of (three) different processes (i.e., ice melt, snowmelt, and liquid precipitation plus base flow) to the outflows from the glacier.

Such flow components are simulated by the model at the hourly scale (and subsequently aggregated at the daily scale, as reported in Figure 4), and occur in a given day, while the simulated stream flows and their timing depend upon the response time of the catchment (Table 3) and integrates contributions from different days, so direct comparison is qualitative. 
During the period 2010-2013 (with complete simulations yearly), the WKN flow average is estimated as $E[Q]=28.70 \mathrm{l} \mathrm{s}^{-1}$, and the mean contributions are $E\left[Q_{i}\right]=20.751 \mathrm{~s}^{-1}$, i.e., $72 \%$, $E\left[Q_{s}\right]=5.81 \mathrm{l} \mathrm{s}^{-1}$, i.e., $20 \%$, and $E\left[Q_{r b}\right]=2.141 \mathrm{~s}^{-1}$, or $8 \%$, for ice, snow melt, and rainfall + base flow, respectively. However, ice melt reaches nearly 100\% of share during most of the thaw season, i.e., from May to October.

While flow recession in fall mostly ends abruptly, fall 2010 displays a slightly longer period of melt than the following years, which is likely given by higher temperatures as visible. Here, simulations with longer past records may help in highlighting (long-term) impacts of weather upon hydrological dynamics.

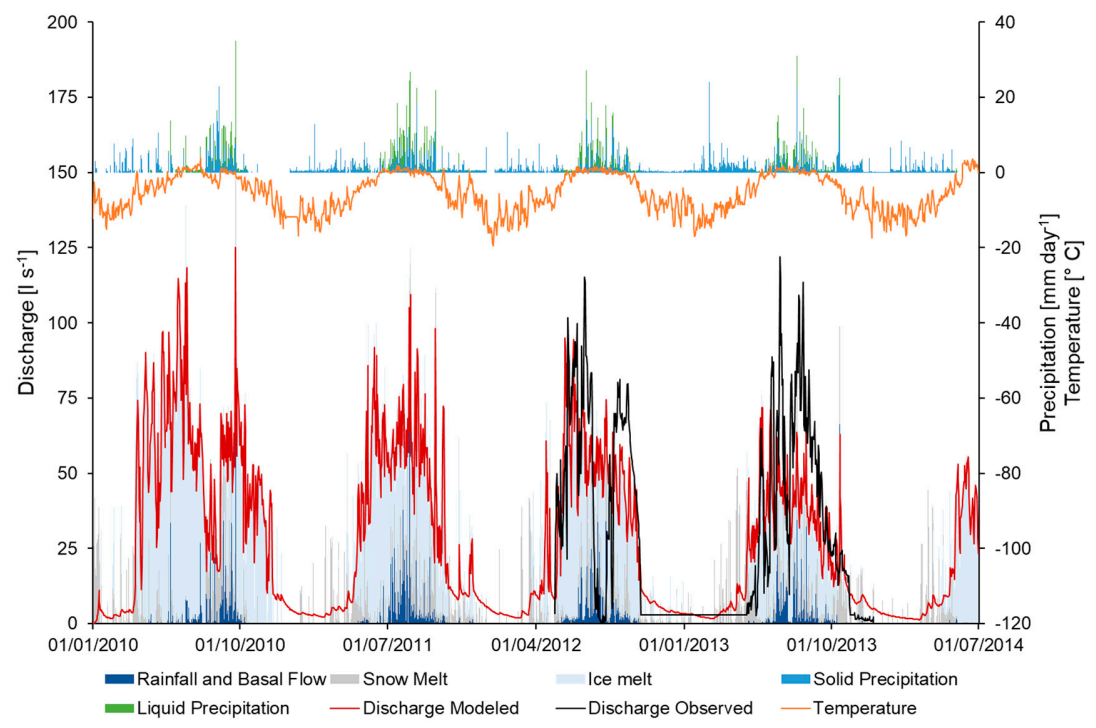

Figure 4. West Khangri Nup hydro station (5332 m asl). Observed (2012-2013) and simulated discharge 2010-2014 (30 June) using Poli-Hydro. We report the simulated daily contributions to flow, i.e., ice/snow melting, rainfall, and base flow, together with the precipitation input of snowfall/rainfall and air temperature.

Table 4. West Khangri Nup. Statistics of modeled ice melt, snow melt, and snow depth, calibration (ice melt and snow melt), validation (snow depth), and mixed (ice melt + snow melt, i.e., total melt available). See Figure 2 for observed and estimated values and dates. Hydro station. Statistics observed and modeled by Poli-Hydro, calibration and validation period. NSE: Nash-Sutcliffe efficiency.

\begin{tabular}{|c|c|c|}
\hline Ice/Snow Melt & Bias\%/NSE/RMSE Calib. & Bias\%/NSE/RMSE Valid. (HS) \\
\hline Ice melt Bias\% $(\%)$ & -2.40 & - \\
\hline Ice melt NSE (.) & 0.64 & - \\
\hline Ice melt RMSE (mm WE) & 501.4 & - \\
\hline Snow melt Bias\%(\%) & -3.71 & - \\
\hline Snow melt NSE (.) & 0.38 & - \\
\hline Snow melt RMSE (mm WE) & 13.02 & - \\
\hline Snow depth Bias\% (\%) & - & 11.94 \\
\hline Snow depth NSE (.) & - & 0.71 \\
\hline Snow depth RMSE (mm WE) & - & 23.3 \\
\hline Snow melt + Ice melt Bias $\%(\%)$ & - & -7.10 \\
\hline Snow melt + Ice melt NSE (.) & - & 0.63 \\
\hline Snow melt + Ice melt RMSE (mm WE) & - & 272.1 \\
\hline Khangri Hydro & Calibration (2012) & Validation (2013) \\
\hline Area $\left(\mathrm{km}^{2}\right)$ & 0.35 & 0.35 \\
\hline Ice covered area $\left(\mathrm{km}^{2}\right)$ & 0.23 & 0.23 \\
\hline$Q_{o b s}\left(1 \mathrm{~s}^{-1}\right)$ Year & 35.17 & 23.78 \\
\hline$Q_{\text {mod }}\left(1 \mathrm{~s}^{-1}\right)$ Year & 35.47 & 20.95 \\
\hline Bias (\%) Year & $0.85 \%$ & $-11.90 \%$ \\
\hline NSE (.) Hourly & 0.341 & 0.312 \\
\hline NSE (.) Daily & 0.456 & 0.466 \\
\hline NSE (.) Monthly & 0.793 & 0.745 \\
\hline
\end{tabular}




\subsection{Snow Pit and $\delta^{18} \mathrm{O}$}

Figure 5 demonstrates the findings concerning the snow pit measurements at WKN EV2CNR station (5601 m asl) on 4 May 2014. Therein, we report (top-left) the measured snow density at 15 points along the vertical profile, together with the modeled counterpart from Poli-Hydro. In addition, we report the measured $\delta^{18} O$ values. Of the 11 sampled points, the two first displayed some disturbances, which was likely due to their proximity to the upper layer and the atmosphere, so we only considered the nine deepest samples, reported in Figure 5. At each depth, we report the average of the two taken samples; however, these were substantially homogeneous.

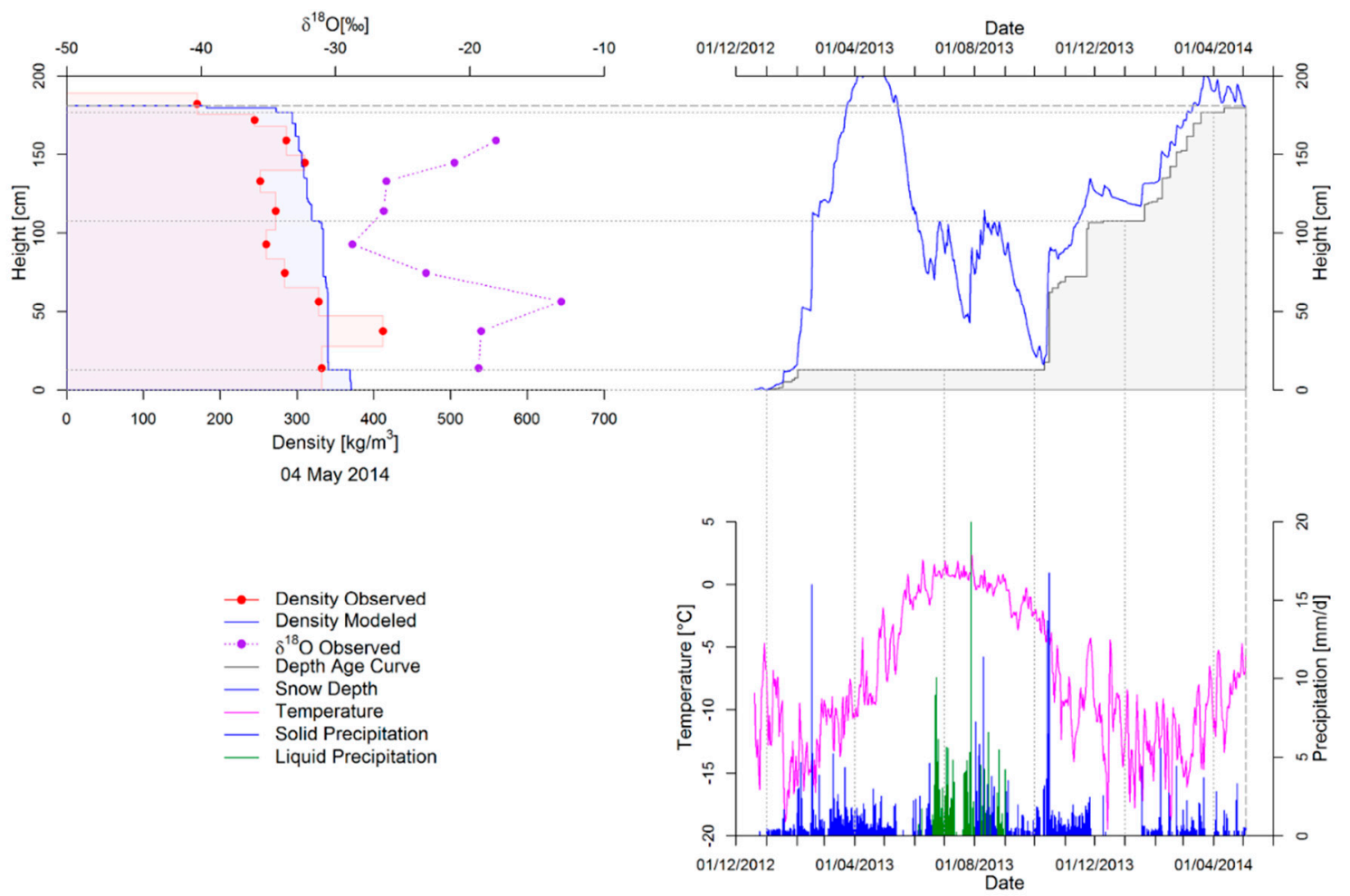

Figure 5. West Khangri Nup EV2CNR station (5601 m asl) snow pit on 4 May 2014. Top-left: Observed and Poli-Hydro simulated snow depth. Measured mass density and $\delta^{18} O$ profile. Top-right: Poli-Hydro simulated snow depth and observed snow layers in the snow pit. Bottom-right: Precipitation partitioning and temperature during the 4 May 2014 snow pack accumulation period (explained in Section 5.3).

We report in the same figure (top-right) the simulated snow depth at the pit (cell) and a curve linking each layer to the corresponding date of deposition, which was back-calculated using Poli-Hydro (taking the snow layer at the intermediate depth of the 11 density samples on the snow pit date).

In the bottom-right panel, we report the daily (measured, West Khangri Nup station) temperature, daily measured (Pyramid) precipitation, and partition (by Poli-Hydro) into liquid/solid, at the same dates above.

First, one gathers the snowpack as present on 4 May 2014 according to our modeling originates not earlier than December 2012-January 2013, i.e., the snow pack should not be older than one and a half years. During January-October 2013, snowpack increased (blue line) until May 2013, and subsequently melted until October 2013. The sole remaining part of the snowpack at October 2013 is the one deposited in February 2013, everything else having melted away ever after. As from the $T / P$ chart, during January-May 2013, the temperature was below freezing, and precipitation was solid (snowfall), thus leading to snow accumulation. After June 2013, the temperature rose mostly above zero, and precipitation was liquid, with subsequent snow melting until October 2013. 
After that date, snowfall occurs toward fall 2013, and snow accumulated above the remaining substrate (from February 2013) as reported. Ever since, snow mostly accumulated, and $T$ was always below zero daily, with sporadic melting hourly starting in April. As a result, the snow pit in 4 May 2014 found ca. $1.70 \mathrm{~m}$ of snow pack, resulting mostly from accumulation during winter 2014 and with (possibly) little contribution from 2013 as reported. The simulated snow density profile (blue line top left) is consistent with such results. In fact, $\rho_{s}$ increases regularly moving down the snow profile, until a sudden break is seen at ca. $10 \mathrm{~cm}$ from the ground, where old snow is modeled to have survived the past winter (2013). The measured snow density profile seemingly displays a consistent behavior with an increasing trend with depth, albeit with some scatter. The isotopic profile indicates a decrease of $\delta^{18} \mathrm{O}$ content from ca. $160 \mathrm{~cm}$ to ca. $100 \mathrm{~cm}$, subsequently increasing until $50 \mathrm{~cm}$ or so, with some scatter at the bottom. In Figure 6, we provide the correspondence between the estimated dates of deposition of the snow layers, corresponding simulated and observed snow density, and the measured $\delta^{18} \mathrm{O}$, together with observed temperature, and a trend line for the latter to aid seasonal trend assessment.

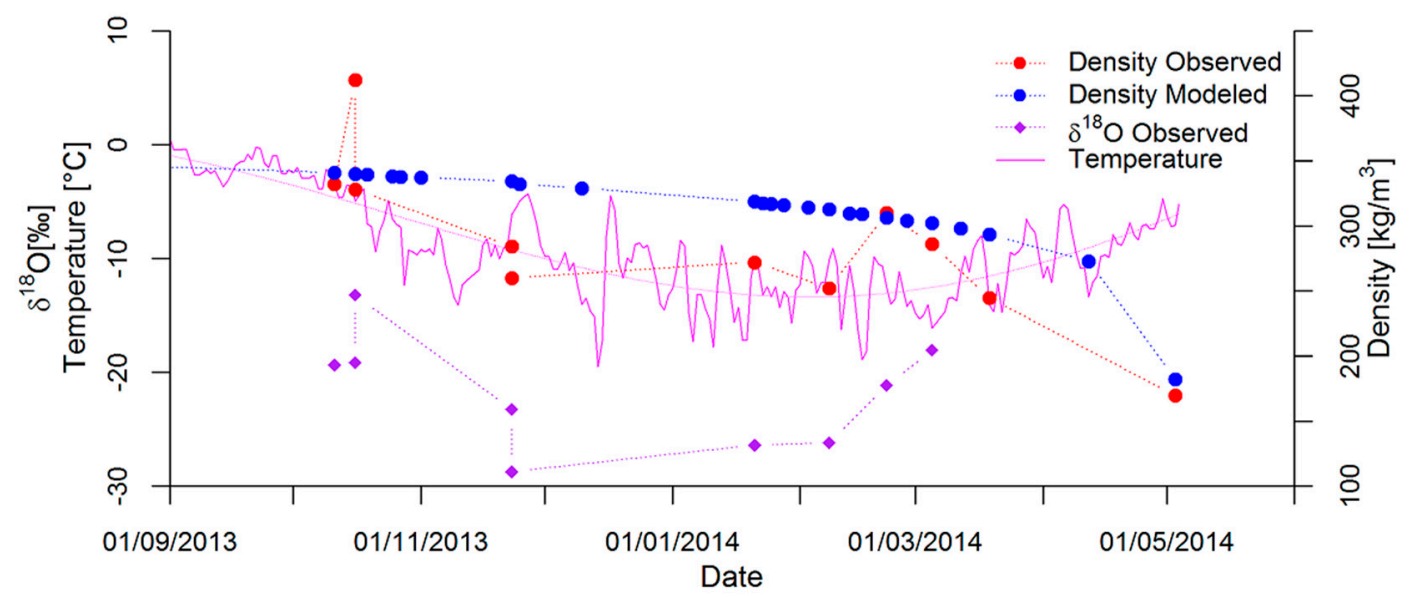

Figure 6. West Khangri Nup EV2CNR station (5601 m asl). Poli-Hydro estimated dates of deposition of the snow layers identified in the snow pit on 4 May 2014, the corresponding simulated and observed snow density of the layer, and the measured isotopic content $\left(\delta^{18} O\right)$. Observed temperature also reported. Binomial interpolation of temperature provided to aid general trend assessment.

From Figure 6, the oldest snow layers (i.e., those with the oldest date of deposition, which are in the left part of the chart) have the highest simulated snow density and highest observed density generally. Further, the measured $\delta^{18} O$ for a certain layer displays a variability consistent with the behavior of temperature during the period (date) of deposition of the layer itself. For instance, the lowest values of the measured $\delta^{18} \mathrm{O}$ appear during the end of November 2013 to half February 2014, i.e., when $T$ is the lowest (down to $-12{ }^{\circ} \mathrm{C}$ or so on average). Subsequently, during March 2014, with increasing temperature, $\delta^{18} \mathrm{O}$ increases as well.

\subsection{Accumulation and Mass Balance on West Khangri Nup Glacier}

We applied here Poli-Hydro for assessment of the spatially distributed mass balance over the glacier, the results of which we report in Figure 7 for the simulation period 2010-2014 (30 June). Daily (jth day) cumulated mass balance over a period $\Delta T$ is here defined in each cell $k$ as i.e., the cumulated budget of snowfall precipitation $(+)$, and snow and ice melt $(-)$, with units of $m$ of water equivalent (m WE).

$$
M B_{k}(\Delta T)=\sum_{j=1}^{\Delta T} S W E_{n, k, j}-M_{s, k, j}-M_{i, k, j}
$$

Visibly, mass balance is negative everywhere, oscillating between $-14.8 \mathrm{~m}$ WE (and $-3.29 \mathrm{~m}$ $\mathrm{WE}$ year $\left.^{-1}\right)$ at the lowest altitudes to $-6.89 \mathrm{~m} \mathrm{WE}\left(-1.53 \mathrm{~m} \mathrm{WE} \mathrm{year}^{-1}\right)$ in the highest parts 
(i.e., the southernmost shaded area, with the largest slopes). On average, there is $-10.45 \mathrm{~m} \mathrm{WE}$ $\left(-2.32 \mathrm{~m} \mathrm{WE} \mathrm{year}^{-1}\right)$.

When considering ice only, the mass balance (meter of ice water equivalent melt, $\mathrm{m}$ IWE) ranges from $-14.99 \mathrm{~m}$ IWE (and $-3.33 \mathrm{~m}$ IWE year ${ }^{-1}$ ) to $-7.08 \mathrm{~m}$ IWE $\left(-1.57 \mathrm{~m} \mathrm{IWE} \mathrm{year}^{-1}\right.$ ) with an average of $-10.77 \mathrm{~m}$ IWE $\left(-2.37 \mathrm{~m}\right.$ IWE year $\left.{ }^{-1}\right)$, clearly indicating a very small contribution of snow cover to mass balance overall, as snow cover does not persist to the end of the hydrologic year. During the simulation period, in spite of the observed snow persistence in some years, in no area (cell) snow cover persisted constantly, and ice melting occurred in all cells in the simulation.

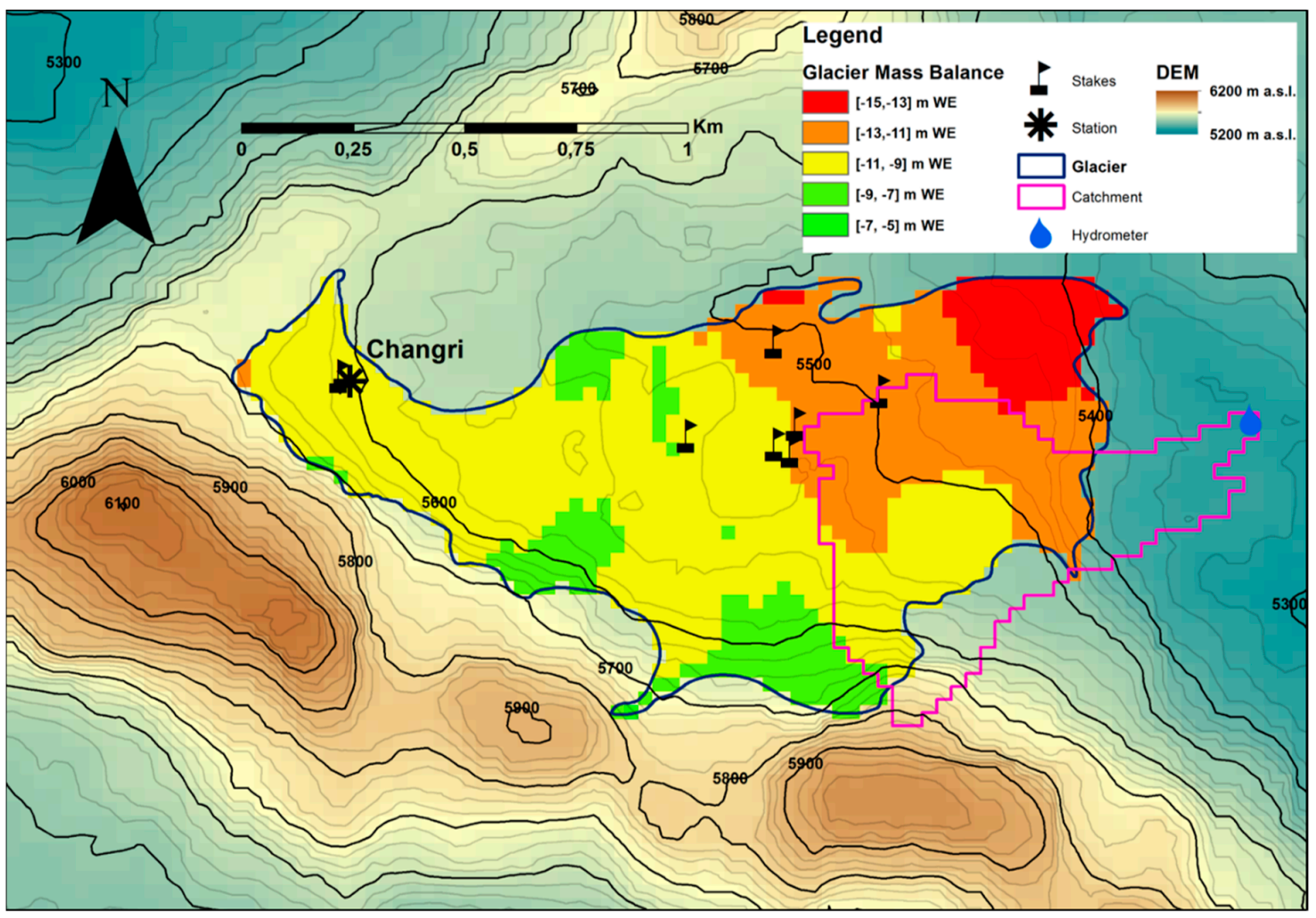

Figure 7. West Khangri Nup glacier. Spatially distributed mass balance (MB) (Equation (2)) in m of water equivalent (m WE), during 2010-2014 (30 June).

\section{Discussion}

\subsection{Isotopic Measurements on the West Khangri Nup Glacier}

The Poli-Hydro model seems reasonably well capable of capturing mass balance, at least within the ablation zone of the glacier, as already witnessed in other recent studies [10,75], which is consistent with field evidence from our 2014 snow pit. Our measured $\delta^{18} O$ profile demonstrates that the deposition of our snow profile, reaching bare ice below, occurred during a single period of cold weather, i.e., during the winter season (2013-2014), as also confirmed by model snow dating and the density profile.

Among others, Tian et al. [76] provided a comprehensive study of the (complex) behavior of $\delta^{18} \mathrm{O}$ patterns in precipitation within a $1500 \mathrm{~km}$ southwest to northeast transect of the Tibetan Plateau. They demonstrated that strong monsoonal activity in the southern Tibetan Plateau results in high precipitation rates and more depleted isotopes (and less correlation with temperature), which is described as an "amount effect". Moving toward the northeast, the monsoon effect is diminished, and yet a reduced correlation of $\delta^{18} \mathrm{O}$ with temperature is observed, but at the monthly scale. Northern of the Tibetan Plateau where monsoon attenuates, $\delta^{18} \mathrm{O}$ in precipitation shows stronger temperature dependence, which is well visible at the monthly scale (Figure 5 in [76]). 
Ginot et al. [40] analyzed a shallow $(19.8 \mathrm{~m})$ firn-ice core extracted at the summit of Mera Peak at $6376 \mathrm{~m}$ asl in the southern flank of the Nepalese Himalaya range, $30 \mathrm{~km}$ south of WKN here. Among others, they analyzed $\delta^{18} O$ content for a period of 11 years (2000-2010). They found anti-correlated patterns of $\delta^{18} O$ against seasonal temperatures, which they attributed to seasonal cycles, with the depleted (i.e., low values) phase corresponding to the (warmer) monsoon season, and the enriched peaks to (colder) inter-monsoon periods. They suggested that since precipitation is reduced during inter-monsoon seasons at high altitude, part of the enriched events may be missing from the record due to wind erosion of the snow, resulting into a reduced seasonal amplitude.

Pang et al. [41] analyzed several ice cores from the Dasuopu (DSP) Glacier (ca. $110 \mathrm{~km}$ northwest of WKN, three cores in 1997) and the East Rongbuk (ER) Glacier (ca. $20 \mathrm{~km}$ north of WKN, one core in 2002), in the central Himalayas. Among others, they analyzed patterns of $\delta^{18} \mathrm{O}$ against seasonal (monthly) temperature and precipitation records. They found remarkable discrepancy in precipitation seasonality between the two sites and subsequent complex isotopic interpretation. On the ER glacier, precipitation from the summer monsoon seems dominating due to topographic blocking of the moisture from westerlies by Mount Everest, resulting in a negative correlation between the ER $\delta^{18} \mathrm{O}$ and precipitation, according to the "amount effect" [76]. At the DSP site, winter precipitation associated with westerlies is more important, and the $\delta^{18} O$ record may be primarily controlled by westerlies, thus resulting in correlation between the thermal cycles and isotopic record.

Here as reported, measured precipitation at the Pyramid site (snowfall plus rainfall) provided $209.3 \mathrm{~mm}$ on average (2010-2014) in the dry season (JFMAM + OND) and $431.8 \mathrm{~mm}$ on average (2010-2013) in the monsoon season (JJAS), thus displaying a share of ca. $65 \%$ of the yearly precipitation (662.4 $\mathrm{mm}$ year $\left.{ }^{-1}, 2010-2013\right)$ falling during monsoonal summer.

Accordingly, here monsoonal precipitation has a relatively low share when compared to other areas (see e.g., Table 1 in [76], with monsoonal share reaching as high as 93\%). In addition, given the high altitude here, a large share of such precipitation occurs under solid form, with relatively low intensity (max observed value, $9 \mathrm{~mm} \mathrm{day}^{-1}$ ), and therefore occurrence of an "amount effect" seems less likely here. As a benchmark, Tian et al. [76] studied $\delta^{18} O$ in Tuotuohe station, at $4533 \mathrm{~m}$ asl, an altitude comparable with our Pyramid station here. Thereby, they estimated an annual precipitation (rainfall) of ca. $262 \mathrm{~mm}$ (93\% MJJASO), and they found consistent dependence of the seasonal $\delta^{18} \mathrm{O}$ vs $T$ (Figures 3 and 5, in [76]). Here, the measured $\delta^{18} O$ in snow follows reasonably well seasonal $T$, and the $\delta^{18} O$ profile in Figure 5 may be well related to the temperature pattern in one accumulation (winter) season.

Based upon the briefly depicted complexity of snow sample chemical analysis [77], isotopic response to temperature patterns, as driven by seasonal precipitation, and the uncertainty in isotopic distribution assessment thereby, our results in this sense seem reasonably consistent.

\subsection{Accumulation and Mass Balance}

From Figure 2 to Figure 6, here we demonstrated that (i) recently (2010-2014) at the highest altitudes of the West Khangri Nup glacier, snow cover is mostly depleted during the summer season [78], and no significant accumulation may occur, as demonstrated by density and isotopic profile, and (ii) Poli-Hydro may be used to depict reasonably well snow accumulation patterns on the glacier, ice melting at stakes, and hydrological budget from the glacier area.

From Figure 2, snow melt is simulated less well, as witnessed by a low value of NSE $=0.38$ in Table 4. Knowingly, snow melt is largely variable in space, and simulation is complex (e.g., [3]). Notice that in Figure 2 for scale, snowpack values (CW1, Khangri, squares) are to be multiplied by 10 and ice melt values ( $S 3, S 5, S 6, S 7, C W 1$, diamonds) are to be multiplied by 100 , while snow melt (S1-S7, circles) is reported in actual values. Accordingly, on average, snowpack in winter (almost entirely melting at the end of the season) is ca. 10-fold smaller than ice melt, and noise in snow melt and snowpack estimation affects mass balance by two/one order of magnitude less than ice melt. 
As a benchmark for our simulated mass balance, Vuillermoz et al. [69] used meteorological and solar radiation data from the West Khangri Nup AWS station during 2010-2012 to assess the glacier ablation rate and albedo. They carried out energy budget to estimate ice melt therein into about $-4.50 \mathrm{~m}$ IWE, i.e., ca. $-1.50 \mathrm{~m}$ IWE year ${ }^{-1}$. Here at the AWS station, we estimated $-9.08 \mathrm{~m}$ IWE, or $-2.02 \mathrm{~m}$ IWE year ${ }^{-1}$.

Vincent et al. [51] pursued ice melt measurements for the debris-free West Khangri Nup here, and the debris covered tongue nearby. On WKN, eight ablation stakes were placed upon October 28-29 2010, ranging from 5390 to $5600 \mathrm{~m}$ asl, and annual local surface mass balance was assessed until 2015. They report a value of $M B$ variable with altitude, ranging from $-3.5 \mathrm{~m} \mathrm{WE}$ year ${ }^{-1}$ at $5400 \mathrm{~m}$ asl to ca. $-0.25 \mathrm{~m} \mathrm{WE}$ year $^{-1}$ at $5600 \mathrm{~m}$ asl, ca. linearly increasing (Figure 7 in [51]). Considering the average altitude of the WKN as calculated here (5494 $\mathrm{m}$ asl) and the proposed linear trend, one would have on average $M B_{a v}=-1.97 \mathrm{~m} \mathrm{WE}$ year ${ }^{-1}$ against $M B_{a v}=-2.32 \mathrm{~m} \mathrm{WE}$ year ${ }^{-1}$ from our calculation.

Sherpa et al. [52] monitored the WKN glacier during 2010-2015 using eight bamboo sticks to measure ice/snow melt, and meteorological data to assist glacier wide mass balance (in one year, starting in November) based on the glaciological method (i.e., linear interpolation of mass balance with altitude). They estimated a spatially averaged value of $M B_{a v}=-1.24 \pm 0.27 \mathrm{~m} \mathrm{IWE} \mathrm{year}{ }^{-1}$. They validated such value by geodetic mass balance, estimating changes in altitude between two sets of satellite stereo images in 2009 (SPOT5, two images) and 2015 (Plèiades, three images). Thereby, they found $M B_{a v}=-1.11 \pm 0.20 \mathrm{~m} \mathrm{IWE} \mathrm{year}^{-1}$.

The authors also report their estimated altitude of the equilibrium line altitude (ELA) i.e., an (ideal) altitude at which yearly snow accumulation equates yearly total melt, $S W E_{n}=M_{S}+M_{i}$ as given in Equation (2) for three years during 2013-2015 (see Table 3 in [52]). ELA altitude averages there $E L A_{a v}=5594 \mathrm{~m}$ asl (ranging from $5570 \mathrm{~m}$ asl in 2014-2015 to $5620 \mathrm{~m}$ asl in 2013-2014).

These altitude values were obtained by the linear regression of $M B$ against altitudes (glaciological method) and taking ELA as the altitude with $M B_{E L A}=0$.

Here, as reported, we used a different method to assess distributed (i.e., cell wise) mass balance. Notice that in our method, snow and ice melt $M_{s, i}$ indeed are calculated in each cell using Equation (1), i.e., as a locally tuned function of temperature and (topographically corrected) local solar radiation. Accordingly, $M B$ is not a simple (i.e., linear) function of altitude (see Figure 7, where different values of $M B$ occur at the same altitude, also depending upon shading), and consequently, a single altitude for ELA cannot be assessed for benchmark.

However, we can qualitatively compare our results here against those in Sherpa et al. [52] by looking at Figure 3 here. Therein, we report the observed temperature and precipitation estimated (by Poli-Hydro) snow depth at the AWS station, at $5601 \mathrm{~m}$ asl, during 2010-2014 (until 30 June). Visibly, during 2013, snow cover as simulated by Poli-Hydro is not entirely depleted in the post-monsoon season, so likely avoiding ice melting underneath. Accordingly, we can indicatively take that the ELA in that period would be lower than $6000 \mathrm{~m}$ asl or so. During summer 2013, Sherpa et al. [52] estimated an $E L A=5595 \mathrm{~m}$ asl (Table 3 in [52], ELA 12/13).

During 2014, instead, snow cover by Poli-Hydro is depleted already in July, and albeit we had to stop our simulation thereby, ice melt would likely start due to a lack of snow cover. Therefore, the $E L A$ in that period would be higher than $6000 \mathrm{~m}$ asl or so. In 2014, Sherpa et al. [52] estimated an $E L A=5620 \mathrm{~m}$ asl (Table 3 in [52], ELA 13/14). Thus, in 2014, the ELA was likely slightly higher than in 2013, and our results are therefore consistent, at least qualitatively, with their findings. King et al. [54] used imagery from several satellites to quantify mass loss (from elevation changes) during 2000-2015 for 32 glaciers in the Everest region. For the WKN glacier, they report a lowering of the glaciers surface (i.e., a proxy of mass loss) of -1 to $-2 \mathrm{~m}$ year $^{-1}$ (Figure 2 in [54]). They also report that the Khumbu glacier (including WKN here) generally has large accumulation above $7000 \mathrm{~m}$ asl.

To further validate our findings, we studied recently available remote sensing information for the covered period (2010-2014, not reported here for shortness), the results of which we briefly illustrate here. Among the theoretically available possible images, which were much reduced by cloud cover (and 
scan line noise for LANDSAT 7), we could use a number (65) of images from LANDSAT 7 (54 images) and LANDSAT 8 (11 images). We used such images to assess the minimum altitude of snow cover in the surroundings of the WKN glacier as a proxy of snow line altitude. Notice also that altitude is not the only driver of snow cover, so at one date the snowline altitude may change spatially. On the white WKN glacier, it is difficult to separate snow/ice in the images, so we stopped the classification of snow altitude at $5330 \mathrm{~m}$ asl, the lowest altitude of the glacier. We subsequently compared the least snow altitude simulated by the Poly-Hydro model on the WKN glacier only. This analysis demonstrated that when LANDSAT satellites would provide a low snow altitude (e.g., during winters), correspondingly, Poli-Hydro would provide the lowest snow altitude at ca. $5330 \mathrm{~m}$ (i.e., the lowest altitude in the simulation), indicating that the glaciers would be covered in snow. When the snow line according to LANDSAT would lift (i.e., in summers), reaching ca. $5330 \mathrm{~m}$ asl (i.e., the glacier's toe), accordingly, the model would indicate increasing snow altitude (i.e., the glacier would also start being snow-depleted). Exceptions may occur due to snowfall events also in summer; however, the results seem broadly concordant and indicate that we basically captured the main features of the snow cover dynamics on the glacier.

From our simulation, snowline altitude was higher than $5330 \mathrm{~m}$ asl (i.e., the glacier was snow free, at least partly) for 272 consecutive days in 2010, and 183, 184, and 171 days, in 2011, 2012, and 2013, respectively. In 2014 until July we estimated 66 days of bare ice. The ice-free period would start in between mid-March and mid-April, changing with the year.

\subsection{Hydrological Flows}

Here, flow discharges from a small contributing area $\left(0.35 \mathrm{~km}^{2}\right)$, including a part of the WKN glacier $\left(0.23 \mathrm{~km}^{2}\right)$ are available during 2012 and 2013, which constitute a precious source to assess water outputs integrated over such a glacier area, and thus the mass budget therein.

As a benchmark, Soncini et al. [8] studied hydrological fluxes at Pherice, where a hydrometric station is operating on the Dudh Koshi river downstream of the WKN here $\left(151 \mathrm{~km}^{2}, 62 \mathrm{~km}^{2}\right.$ covered with ice). They tuned the Poli-Hydro model during 2012, and subsequently validated its performance during 2013-2014 obtaining (daily scale) Bias $\%=-4.39 \% /+11.94 \%$, respectively $(+0.855 /-11.90 \%$ here), and NSE $=0.93 / 0.69$, respectively (here, $0.46 / 0.47$ ). However, prior to proper hydrological modeling, the authors of that study had to accurately explore precipitation dependence upon altitude in the area, which is largely uncertain as reported.

Direct (i.e., overland flow) ice contribution to stream flows during 2012-2014 was estimated into $55 \%$, and snow contribution is estimated into $19 \%$, which is consistent with the results from the WKN reported here, laid upstream of Pheriche, and featuring therefore a larger ice-covered area, and ice melt flow component.

Mimeau et al. [67] also studied hydrological flow components in the Dudh Koshi river closed at Pheriche. During 2012-2015, they estimated an ice flow contribution ranging from $41 \%$ to $71 \%$ (average $58 \%$, Figure 7 in [67]), and snow contribution ranging from $23 \%$ to $47 \%$ (average $31 \%$, Figure 7 in [67]); however, this was dependent largely on the year (2012-2013, 2013-2014, 2014-2015), ice/snow melt parameterization, uncertainly estimated ice/snow-covered areas, and different definitions of the flow components.

Savéan et al. [37] studied the water budget of the Dudh Koshi river at Rabuwa Bazar $\left(3720 \mathrm{~km}^{2}\right.$, ca. $390 \mathrm{~km}^{2}$ ice covered), much downstream of Pheriche here, using five years of hydrological data (2001-2005) from the Department of Hydrology and Meteorology (DHM) of Nepal. They assessed the main terms of water budget, especially the mean annual volume of precipitation $\left(\sim 1150 \mathrm{~mm} \mathrm{year}^{-1}\right)$ and the mean annual volume of flow $\left(\sim 2300 \mathrm{~mm}_{\text {year }}{ }^{-1}\right)$, concluding that the runoff coefficient is always greater than 1.5, and on average 2.1 from February 2001 to May 2004, thus providing an unbalanced water budget by approximately $1200 \mathrm{~mm}_{\text {year }}{ }^{-1}$. They obtained an acceptable performance using the Hydrological Distributed Snow Model (HDSM) with back-estimated precipitation from hydrological flows (reverse hydrology, e.g., [34]). Albeit such an approach may be questionable, clearly, 
knowledge of stream flows may help in evaluating the accuracy of precipitation measurements in poorly monitored, high-altitude areas as shown here.

Bocchiola (unpublished data) was able to reproduce fairly well (Bias $\%=0.54 \%$, NSE $=0.69$ ) the hydrology of the Dudh Koshi river, which was closed much downstream at Rabuwa Bazar, during 1964-2013, by properly accounting for precipitation vertical lapse rates, changing from monsoon (May to October) to dry season (November to April), as suggested, e.g., in [31], based upon ground observations. However, the hydrology of these high areas remains complex.

Ragettli et al. [38] studied the flow components of the upper Langtang basin $\left(350 \mathrm{~km}^{2}, \mathrm{ca} .95 \mathrm{~km}^{2}\right.$ ice cover) in Nepal using one year of flow measurements from two stations at the toe of Lirung glacier (ca. 3700-4000 $\mathrm{m}$ asl). Using a multi-parameter (13 parameters) tuning procedure against ground and remote sensing data, they obtain a best-case $N S E=0.87$, while they suggest that the hydrology of such high-elevation watersheds of the Hindu Kush-Himalaya region (HKH) is still little known due to a lack of missing data of precipitation and runoff, as well as poor knowledge of the undergoing physical processes.

In view of the considerable altitude of the WKN catchment and of the objective complexity of installing and managing hydrometric stations in this area, the results of the Poli-Hydro modeling exercise here seem acceptable, and they provide a depiction of flow dynamics, and origin for the area, while indirectly validating the calculated mass balances therein.

Here, given the very high altitude of the catchment, we highlighted a large contribution of snow and especially ice melting, decreasing with mean catchment altitude (see [8] for a discussion of flow contribution in the area); so, validation of the ice melt contribution is likely better achieved, because in practice, very little water is coming from other sources (i.e., uncertain rainfall over the catchment, as occurring further downstream).

Clearly, the proposed results of this high-flow measuring station represent a somewhat extreme hydrological application and may display some inconsistencies. Mainly during the summer season of 2012, malfunctioning of the sensor may have occurred. In addition, given the position of the hydro station, right below the glacier, sediment transport was occurring, so the drum hosting the station might have been filled with sediment. The personnel of the Pyramid would visit the station regularly during the warmer season and clean up the station whenever possible. Accordingly, periods of less proper functioning may depend upon this circumstance. Doubts upon the flow component may surely persist of course, but our results seem acceptably consistent.

\subsection{Limitations and Outlooks}

The West Khangri Nup is a small, debris-free glacier that is likely not representative of the full spectrum of glaciers of the Himalayas. Recent evidences (see e.g., [79]) suggest that debris-covered glaciers in the Himalayas appear to have thinning rates similar to debris-free glaciers, in spite of the well-known insulating effect of debris cover on ice beneath [80], which is a phenomenon called "debris cover anomaly". Among others, Brun et al. [79] used data from an unmanned aerial vehicle (UAV), and from satellites to quantify ice loss (i.e., using stereophotogrammetry) from the debris-covered Khangri Nup, north of the WKN here, during 2015-2017. Based on their results, they hypothesize that the debris-cover anomaly could be a result of (i) lower emergence velocities (upward ice flux), (ii) reduced ablation, and (iii) formation of ice cliffs and supraglacial ponds, which may contribute disproportionately to the average tongue ablation over debris-covered glaciers., and lead to thinning rates comparable to those observed on clean ice glaciers. In this sense, the local investigation of debris-free/covered ablation in the Khangri area is of large interest, as well as assessment of flow/emergence velocities, which might be studied henceforth.

Accordingly, knowledge of this specific glacier may aid in increasing knowledge of the glaciers' condition, down wasting dynamics in this area, and the Himalayas in general, providing a benchmark for other scientists in the area [81]. 
Our modeling exercise has clearly limitations inherent to complex conditions for field studies. Our ice ablation model of WKN glacier was set up using some stakes on the ground, and it was operated for two years only. The use of ice stakes, notwithstanding complex operation in the high altitudes, remains a most accurate method for assessing ice ablation, but longer series may be required for more accurate melt assessment and model tuning. However, the WKN is small and flat enough that the chosen stakes may be thought of as representative of the overall behavior of the glacier.

We could use temperature and radiation data directly from the WKN station, which made such variables representative of the investigated area, and even precipitation was taken at Pyramid, which is relatively close, and at a relatively similar altitude. In addition, snow depth HS dynamics was assessed based upon measurements at the Pyramid site (and fresh snow density was also assessed from samples therein during summer 2014, as reported).

Such circumstances clearly helped in providing a representative modeling of the area. The vertical extent of the glacier we studied covers ca. $200 \mathrm{~m}$, so we would not expect very large changes of precipitation with altitude. Still, the interpolation method may carry some bearing upon the mass budget. However, we were able to constrain the uncertainty coming from interpolation over long distances, or large vertical jumps, often affecting model results. We hopefully reduced uncertainty in precipitation (amount, liquid/solid partition), as witnessed by acceptably low bias in water budget assessment, and thus in mass balance estimation.

The digging of a snow pit and subsequent assessment of snow density stratification and isotopic profile helped largely to assess accumulation patterns in the transient accumulation zone.

Hydrological flow data for this calibration/validation exercise were available for a short period, which is typical of high-altitude basins, and here specifically from a rather peculiar installation, and yet they were precious for the validation of mass balance, and to highlight flow components from the different sources.

Improvement may come from the use of more precipitation/snow gauges in the area, maybe at the Khangri AWS site, and in general within the Khumbu area, at as high as possible sites. Snow cover dynamics is very erratic in space [3], and denser networks are needed to get a better picture, also in view of the potentially large noise in snow melt simulation, as reported here in Figure 2.

Our ice/snow melt modeling approach is simple and yet dependable enough, and it includes the use of radiation, which is very important in this area. The hourly depiction of melt processes helped in sketching sub-daily cycles of freeze/thaw, clear/cloudy sky, etc., which is also very important in the Khumbu area, where large thermal excursion occurs every day, and rapid cloud/precipitation dynamics is observed. An energy-based melt model (e.g., [82]) may help in capturing ablation dynamics even better, and it may be developed henceforward.

One may pursue model sensitivity analysis for tuning ice/snow melt, snowpack dynamics, and hydrological parameters; however, these are mostly constrained here against measurements, so no large degree of freedom is left (see e.g., [7] for a discussion about unconstrained/ill-posed modeling in high altitude areas). Certainly, new field data may improve parameterization.

Little can be said about changes in ablation as related to global warming here, given that the simulated series of stream flow is very short in this sense. However, Poly-Hydro could be used henceforth to investigate the prospective behavior of this specific glacier under future climate change (e.g., [8], for a similar exercise covering the Khumbu glacier).

\section{Conclusions}

We exploited here a rather complete, mostly unexploited dataset, including weather, glaciological, hydrological, and isotopic data gathered during recent field campaigns (2010-2014) to thoroughly investigate the present state of the bare WKN glacier, which is a relatively little, and yet representative ice body nested in the Khumbu glacier of the Everest region [79]. We demonstrated that (i) significant snow accumulation is not retained recently, (ii) the last measured snowpack was recent (fall-winter 2013-2014), (iii) large, widespread ice losses occurred on the glacier recently, and (iv) most of the 
hydrological contribution from this area comes from ice melt, and glaciers depletion may imply a large reduction of glacier runoff in this basin (e.g., [6-8]).

The Poli-Hydro model simulated well enough ice melt, which is the dominant source of glacier runoff, while resulting in lower accuracy in the simulation of snow melt, which is largely variable in space.

However, given the small share of runoff as given by snow melt in this specific site, runoff simulation seems to not be significantly affected. However, further efforts should be made to improve this aspect. Cumulated snow pack (HS) was simulated well here, making us confident about our results concerning seasonal snow depletion.

Our study displays an original dataset and results, contributing to the assessment of glaciers mass balance and to the investigation of accumulation zones in the Everest region and the Himalayas in general. It is very necessary to assess the present and potential future dynamics and hydrological contribution therein.

Author Contributions: Conceptualization, D.B.; Methodology, G.M.B. and F.C.; Software, D.B. and G.M.B.; Validation, P.M.O. and F.C.; Formal Analysis, D.B., G.M.B. and F.C.; Investigation, D.B.; Resources, D.B. and F.C.; Data Curation, P.M.O.; Writing-Original Draft Preparation, D.B.; Writing-Review \& Editing, P.M.O. and F.C.; Visualization, G.M.B.; Supervision, D.B.; Project Administration, D.B.; Funding Acquisition, D.B. All authors have read and agreed to the published version of the manuscript.

Funding: This research received no external funding.

Acknowledgments: The present work was carried out in fulfillment of SHARE-Paprika, and SHARE-Dudh Koshi River project, funded by the EVK2CNR Association of Italy, managing among others the Pyramid Laboratory in the Khumbu valley. The scientific activity of the Pyramid is of paramount importance in this area, and yet the activity of the Pyramid Lab has been interrupted since 2015, and glaciological activity is lagging behind accordingly. Should the Pyramid-Lab be re-opened soon enough, one could work to further expand knowledge of the cryosphere in the area, and generally of this high-altitude environment, including continuation of the activity carrying to the present study. The Nepal Academy of Science and Technology (NAST) is kindly acknowledged for providing personnel and logistic assistance. Gianpietro Verza, technical coordinator of the Pyramid laboratory, and the Pyramid staff are kindly acknowledged for their support and assistance during field campaigns, and for data gathering. Elisa Vuillermoz is kindly acknowledged for sharing weather and ice ablation data from the campaigns in 2010-2011. Andrea Soncini, Umberto Minora, Eng. Gabriele Confortola, Dibas Shrestha, Chiara Compostella, Marco Caccianiga, and Roberto Ambrosini are kindly acknowledged for their contributions to field campaigns on Khumbu glacier in 2012 and 2014. Chistoph Mayer and Astrid Lambrecht are kindly acknowledged for sharing information from their field campaigns on Baltoro glacier in fulfillment of SHARE-Paprika. Eng. Vittoria Paramithiotti, Eng. Michela Buizza, and Eng. Andrea Fraschini are kindly acknowledged for providing help in Dudh Koshi/Khangri Nup modeling in fulfillment of their Master Thesis. Guglielmina Diolaiuti and Claudio Smiraglia are kindly acknowledged for cooperation in fulfillment of SHARE-Paprika and SHARE Dudh Koshi River, providing precious discussions on the glaciers' start and fate in the area, and continuous support to the lead author here. Support to the present work was provided in fulfilment of the activity of the Climate-Lab laboratory of Politecnico di Milano (https://www.climatelab.polimi.it/en/), an interdepartmental laboratory on climate change at Politecnico, which is kindly acknowledged.

Conflicts of Interest: The authors declare no conflict of interest.

\section{References}

1. IPCC. Summary for Policymakers. In Climate Change 2013: The Physical Science Basis. Contribution of Working Group I to the Fifth Assessment Report of the Intergovernmental Panel on Climate Change; Stocker, T.F., Qin, D., Plattner, G.-K., Tignor, M., Allen, S.K., Boschung, J., Nauels, A., Xia, Y., Bex, V., Midgley, P.M., Eds.; Cambridge University Press: Cambridge, UK; New York, NY, USA, 2013. Available online: http://www.climatechange2013.org/images/report/WG1AR5_Frontmatter_FINAL.pdf (accessed on 31 July 2019).

2. IPCC. Special Report on the Impacts of Global Warming of $1.5^{\circ} \mathrm{C}$ above Pre-Industrial Levels and Related Global Greenhouse Gas Emission Pathways, in the Context of Strengthening the Global Response to the Threat of Climate Change, Sustainable Development, and Efforts to Eradicate Poverty, in 2018: Global Warming of $1.5^{\circ} \mathrm{C}$. Masson-Delmotte, V.P., Zhai, H.-O., Pörtner, D., Roberts, J., Skea, P.R., Shukla, A., Pirani, W., Moufouma-Okia, C., Péan, R., Pidcock, S., et al., Eds.; 2018. Available online: https://www.ipcc.ch/sr15/download/ (accessed on 11 November 2019). 
3. Bocchiola, D.; Mihalcea, C.; Diolaiuti, G.; Mosconi, B.; Smiraglia, C.; Rosso, R. Flow prediction in high altitude ungauged catchments: A case study in the Italian Alps (Pantano Basin, Adamello Group). Adv. Water Resour. 2010, 33, 1224-1234. [CrossRef]

4. Immerzeel, W.W.; van Beek, L.P.H.; Bierkens, M.F.P. Climate Change Will Affect the Asian Water Towers. Nat. Geosci. 2010, 5984, 1382-1385. [CrossRef]

5. Kaser, G.; Großhauser, M.; Marzeion, B. Contribution potential of glaciers to water availability in different climate regimes. Proc. Natl. Acad. Sci. USA 2010, 107, 20223-20227. [CrossRef] [PubMed]

6. Soncini, A.; Bocchiola, D.; Confortola, G.; Bianchi, A.; Rosso, R.; Mayer, C.; Lambrecht, A.; Palazzi, E.; Smiraglia, C.; Diolaiuti, G. Future hydrological regimes in the Upper Indus basin: A case study from a high-altitude glacierized catchment. J. Hydrometeorol. 2015, 16, 306-326. [CrossRef]

7. Soncini, A.; Bocchiola, D.; Azzoni, R.S.; Diolaiuti, G. A methodology for monitoring and modeling of high altitude Alpine catchments. Prog. Phys. Geogr. 2017, 41, 393-420. [CrossRef]

8. Soncini, A.; Bocchiola, D.; Confortola, G.; Minora, U.; Vuillermoz, E.; Salerno, F.; Viviano, G.; Shrestha, D.; Senese, A.; Smiraglia, C.; et al. Future hydrological regimes and glacier cover in the Everest region: The case study of the upper Dudh Koshi basin. Sci. Total Environ. 2016, 565, 1084-1101. [CrossRef]

9. Baldasso, V.; Soncini, A.; Azzoni, R.S.; Diolaiuti, G.; Bocchiola, D. Recent evolution of glaciers in Western Asia in response to global warming: The case study of mount Ararat, Turkey. Theor. Appl. Climatol. 2018, 1-15. [CrossRef]

10. Bocchiola, D.; Soncini, A.; Senese, A.; Diolaiuti, G. Modelling hydrological components of the Rio Maipo of Chile, and their prospective evolution under climate change. Climate 2018, 6, 57. [CrossRef]

11. Pritchard, H.D. Asia's shrinking glaciers protect large populations from drought stress. Nature 2019, 569, 649-654. [CrossRef]

12. Berthier, E.; Arnaud, Y.; Kumar, R.; Ahmad, S.; Wagnon, P.; Chevallier, P. Remote sensing estimates of glacier mass balances in the Himachal Pradesh (Western Himalaya, India). Remote Sens. Environ. 2007, 108, 327-338. [CrossRef]

13. Salerno, F.; Buraschi, E.; Bruccoleri, G.; Tartari, G.; Smiraglia, C. Glacier surface-area changes in Sagarmatha national park, Nepal, in the second half of the 20th century, by comparison of historical maps. J. Glaciol. 2008, 54, 738-752. [CrossRef]

14. Kehrwald, N.M.; Thompson, L.G.; Tandong, Y.; Mosley-Thompson, E.; Schotterer, U.; Alfimov, V.; Beer, J.; Eikenberg, J.; Davis, M.E. Mass loss on Himalayan glacier endangers water resources. Geophys. Res. Lett. 2008, 35, L22503. [CrossRef]

15. Benn, D.; Bolch, T.; Hands, K.; Gulley, J.; Luckman, A.; Nicholson, L.; Quincey, D.; Thompson, S.; Toumi, R.; Wiseman, S. Response of debris-covered glaciers in the Mount Everest region to recent warming, and implications for outburst flood hazards. Earth-Sci. Rev. 2012, 114, 156-174. [CrossRef]

16. Gardelle, J.; Berthier, E.; Arnaud, Y. Slight mass gain of Karakoram glaciers in the early twenty-first century. Nat. Geosci. Lett. 2012. [CrossRef]

17. Bocchiola, D.; Diolaiuti, G. Recent (1980-2009) evidence of climate change in the upper Karakoram, Pakistan. Theor. Appl. Climatol. 2013, 113, 611-641. [CrossRef]

18. Thakuri, S.; Salerno, F.; Smiraglia, C.; Bolch, T.; D’Agata, C.; Viviano, G.; Tartari, G. Tracing glacier changes since the 1960s on the south slope of Mt. Everest (central Southern Himalaya) using optical satellite imagery. Cryosphere 2014, 8, 1297-1315. [CrossRef]

19. Brun, F.; Berthier, E.; Wagnon, P.; Kääb, A.; Treichler, D. A spatially resolved estimate of High Mountain Asia glacier mass balances from 2000 to 2016. Nat. Geosci. 2017, 10, 668-673. [CrossRef]

20. Azam, M.F.; Wagnon, P.; Berthier, E.; Vincent, C.; Fujita, K.; Kargel, J.S. Review of the status and mass changes of Himalayan-Karakoram glaciers. J. Glaciol. 2018, 1-14. [CrossRef]

21. Mimeau, L.; Esteves, M.; Jacobi, H.-W.; Zin, I. Evaluation of Gridded and In Situ Precipitation Datasets on Modeled Glacio-Hydrologic Response of a Small Glacierized Himalayan Catchment. J. Hydrometeor. 2019, 20, 1103-1121. [CrossRef]

22. Minora, U.; Bocchiola, D.; D’Agata, C.; Maragno, D.; Mayer, C.; Lambrecht, A.; Vuillermoz, E.; Senese, A.; Compostella, C.; Smiraglia, C.; et al. Glacier area stability in the Central Karakoram National Park (Pakistan) in 2001-2010: The "Karakoram Anomaly" in the spotlight. Prog. Phys. Geogr. 2016, 40, 629-660. [CrossRef] 
23. Li, G.; Lin, H.; Ye, Q. Heterogeneous decadal glacier downwasting at the Mt. Everest (Qomolangma) from 2000 to 2012 based on multi-baseline bistatic SAR interferometry. Remote Sens. Environ. 2018, 206, 336-349. [CrossRef]

24. Mayer, C.; Lambrecht, A.; Oerter, H.; Schwikowski, V.E.; Frank, N.; Diolaiuti, G. Accumulation studies at a high elevation glacier site in central Karakoram. Adv. Meteorol. 2014, 215162. [CrossRef]

25. Minora, U.; Senese, A.; Bocchiola, D.; Soncini, A.; D'agata, C.; Ambrosini, R.; Mayer, C.; Lambrecht, A.; Vuillermoz, E.; Smiraglia, C.; et al. A simple model to evaluate ice melt over the ablation area of glaciers in the Central Karakoram National Park, Pakistan. Ann. Glaciol. 2015, 56, 202-216. [CrossRef]

26. Pellicciotti, F.; Brock, B.; Strasser, U.; Burlando, P.; Funk, M.; Corripio, J. An enhanced temperature-index glacier melt model including the shortwave radiation balance: Development and testing for Haut Glacier d'Arolla, Switzerland. J. Glaciol. 2005, 51, 573-587. [CrossRef]

27. Higuchi, K.; Ageta, Y.; Yasunari, T.; Inoue, J. Characteristics of precipitation during the monsoon season in high-mountain areas of the Nepal Himalaya. In Proceedings of the Conference: Hydrological Aspects of Alpine and High Mountain Areas, Exeter, UK, 19-30 July 1982; pp. 21-30.

28. Immerzeel, W.W.; Petersen, L.; Ragettli, S.; Pellicciotti, F. The importance of observed gradients of air temperature and precipitation for modeling runoff from a glacierized watershed in the Nepalese Himalayas. Water Resour. Res. 2014, 50, 2212-2226. [CrossRef]

29. Winiger, M.; Gumpert, M.; Yamout, H. Karakoram-Hindukush-western Himalaya: Assessing high-altitude water resources. Hydrol. Process. 2005, 19, 2329-2338. [CrossRef]

30. Rowan, A.V.; Egholm, D.L.; Quincey, D.J.; Glasser, N.F. Modelling the feedbacks between mass balance, ice flow and debris transport to predict the response to climate change of debris-covered glaciers in the Himalaya. Earth Planet. Sci. Lett. 2015, 430, 427-438. [CrossRef]

31. Salerno, F.; Guyennon, N.; Thakuri, S.; Viviano, G.; Romano, E.; Vuillermoz, E.; Cristofanelli, P.; Stocchi, P.; Agrillo, G.; Ma, Y.; et al. Weak precipitation, warm winters and Springs impact glaciers of south slopes of Mt. Everest (central Himalaya) in the last 2 decades (1994-2013). Cryosphere 2015, 9, 1229-1247. [CrossRef]

32. Yatagai, A.; Kamiguchi, K.; Arakawa, O.; Hamada, A.; Yasutomi, N.; Kitoh, A. APHRODITE: Constructing a Long-Term Daily Gridded Precipitation Dataset for Asia Based on a Dense Network of Rain Gauges. Bull. Am. Meteor. Soc. 2012, 93, 1401-1415. [CrossRef]

33. Bookhagen, B.; Burbank, D.W. Topography, relief, and TRMM-derived rainfall variations along the Himalaya. Geophys. Res. Lett. 2006, 33, L08405. [CrossRef]

34. Kirchner, J.W. Catchments as simple dynamical systems: Catchment characterization, rainfall-runoff modeling, and doing hydrology backward. Water Resour. Res. 2009, 45, 2135. [CrossRef]

35. Immerzeel, W.; Pellicciotti, F.; Shrestha, A.B. Glaciers as a proxy to quantify the spatial distribution of precipitation in the Hunza basin. Mt. Res. Dev. 2012, 32, 30-38. [CrossRef]

36. Khan, A.J.; Koch, M. Correction and Informed Regionalization of Precipitation Data in a High. Mountainous Region. ${ }^{\mathrm{TM}}$ (Upper Indus Basin) and Its Effect on SWAT-Modelled Discharge. Water 2018, 10, 1557. [CrossRef]

37. Savéan, M.; Delclaux, F.; Chevallier, P.; Wagnon, P.; Gonga-Saholiariliva, N.; Sharma, R.; Neppel, L.; Arnaud, Y. Water budget on the Dudh Koshi River (Nepal): Uncertainties on precipitation. J. Hydrol. 2015, 531, 850-862. [CrossRef]

38. Ragettli, S.; Pellicciotti, F.; Immerzeel, W.W.; Miles, E.S.; Petersen, L.; Heynen, M.; Shea, J.M.; Stumm, D.; Joshi, S.; Shrestha, A. Unraveling the hydrology of a Himalayan catchment through integration of high resolution in situ data and remote sensing with an advanced simulation model. Adv. Water Resour. 2015, 78, 94-111. [CrossRef]

39. Immerzeel, W.W.; Pellicciotti, F.; Bierkens, M.F.P. Rising river flows throughout the twenty-first century in two Himalayan glacierized watersheds. Nat. Geosci. 2013, 6, 1-4. [CrossRef]

40. Ginot, P.; Dumont, M.; Lim, S.; Patris, N.; Taupin, J.-D.; Wagnon, P.; Gilbert, A.; Arnaud, Y.; Marinoni, A.; Bonasoni, P.; et al. A 10 year record of black carbon and dust from a Mera Peak ice core (Nepal): Variability and potential impact on melting of Himalayan glaciers. Cryosphere 2014, 8, 1479-1496. [CrossRef]

41. Pang, H.; Hou, S.; Kaspari, S.; Mayewski, P.A. Influence of regional precipitation patterns on stable isotopes in ice cores from the central Himalayas. Cryosphere 2014, 8, 289-301. [CrossRef]

42. Dansgaard, W. Stable isotopes in precipitation. Tellus 1964, 16, 436-468. [CrossRef]

43. Brown, S.; Shrestha, B. Market.-driven land-use dynamics in the middle mountains of Nepal. J. Environ. Manag. 2000, 59, 217-225. [CrossRef] 
44. Tripathi, R.S.; Sah, V.K. Material and energy flows in high-hill, mid-hill and valley farming systems of Garhwal Himalaya. Agric. Ecosyst. Environ. 2001, 86, 75-91. [CrossRef]

45. Palazzoli, I.; Maskey, S.; Uhlenbrook, S.; Nana, E.; Bocchiola, D. Impact of prospective climate change upon water resources and crop yield in the Indrawati basin, Nepal. Agric. Syst. 2015, 133, 143-157. [CrossRef]

46. Bocchiola, D.; Pelosi, M.G.; Soncini, A. Effects of hydrological changes on cooperation in transnational catchments: The case of the Syr Darya. Water Int. 2017, 42, 852-873. [CrossRef]

47. Bocchiola, D.; Soncini, A. Water resources modeling and prospective evaluation in the Indus River under present and prospective climate change. In Indus River Basin: Water Security and Sustainability; Khan, S., Adams, T., Eds.; Elsevier: Amsterdam, The Netherlands, 2019; p. 500, ISBN 9780128127827.

48. Pokharel, S. Kyoto protocol and Nepal's energy sector. Energy Policy 2007, 35, 2514-2525. [CrossRef]

49. Hussain, A.; Sarangi, G.K.; Pandit, A.; Ishaq, S.; Mamnun, N.; Ahmad, B.; Jamil, M.K. Hydropower development in the Hindu Kush Himalayan region: Issues, policies and opportunities. Renew. Sustain. Energy Rev. 2019, 107, 446-461. [CrossRef]

50. Bocchiola, D.; Manara, M.; Mereu, M. Impact of prospective climate change on Run of River hydropower schemes in the Himalayas: The case study of the Dudh Koshi basin of Nepal. Energy 2019, submitted.

51. Vincent, C.; Wagnon, P.; Shea, J.; Immerzeel, W.; Kraaijenbrink, P. Reduced melt on debris-covered glaciers: Investigations from Changri Nup Glacier, Nepal. Cryosphere 2016, 10, 1845-1858. [CrossRef]

52. Sherpa, S.F.; Wagnon, P.; Brun, F.; Berthier, E.; Vincent, C.; Lejeune, Y.; Arnaud, Y.; Kayastha, R.B.; Sinisalo, A. Contrasted surface mass balances of debris-free glaciers observed between the southern and the inner parts of the Everest region (2007-2015). J. Glaciol. 2017, 63, 637-651. [CrossRef]

53. Bolch, T.; Pieczonka, T.; Benn, D.I. Multi-decadal mass loss of glaciers in the Everest area (Nepal Himalaya) derived from stereo imagery. Cryosphere 2011, 5, 349-358. [CrossRef]

54. King, O.; Quincey, D.J.; Carrivick, J.L.; Rowan, A.V. Spatial variability in mass loss of glaciers in the Everest region, central Himalayas, between 2000 and 2015. Cryosphere 2017, 11, 407-426. [CrossRef]

55. Shea, J.M.; Immerzeel, W.W.; Wagnon, P.; Vincent, C.; Bajracharya, S. Modelling glacier change in the Everest region, Nepal Himalaya. Cryosphere 2015, 9, 1105-1128. [CrossRef]

56. Del Bello, L. Mothballed Mount Everest climate observatory could reopen by early next year. Nat. News 2018, 563, 17-18. [CrossRef] [PubMed]

57. Tartari, G.; Salerno, F.; Buraschi, E.; Bruccoleri, G.; Smiraglia, C. Lake surface area variations in the North-Eastern sector of Sagarmatha National Park (Nepal) at the end of the 20th Century by comparison of historical maps. J. Limnol. 2008, 67, 139-154. [CrossRef]

58. Amatya, L.K.; Cuccillato, E.; Haack, B.; Shadie, P.; Sattar, N.; Bajracharya, B.; Shrestha, B.; Caroli, P.; Panzeri, D.; Basani, M.; et al. Improving communication for management of social and ecological systems in high mountain areas. Mt. Res. Dev. 2010, 30, 69-79. [CrossRef]

59. Salerno, F.; Viviano, G.; Mangredi, E.C.; Caroli, P.; Thakuri, S.; Tartari, G. Multiple Carrying Capacities from a management-oriented perspective to operationalize sustainable tourism in protected area. J. Environ. Manag. 2013, 128, 116-125. [CrossRef] [PubMed]

60. Yao, T.; Thompson, L.; Yang, W.; Yu, W.; Gao, Y.; Guo, X.; Yang, X.; Duan, K.; Zhao, H.; Xu, B.; et al. Different glacier status with atmospheric circulations in Tibetan Plateau and surroundings. Nat. Clim. Chang. 2012, 2, 663-667. [CrossRef]

61. Zemp, M.; Hoelzle, M.; Haeberli, W. Six decades of glacier mass-balance observations: A review of the worldwide monitoring network. Ann. Glaciol. 2009, 50, 101-111. [CrossRef]

62. Peel, M.C.; Finlayson, B.L.; McMahon, T.A. Updated world map of the Köppen-Geiger climate classification. Hydrol. Earth Syst. Sci. 2007, 11, 1633-1644. [CrossRef]

63. Karki, R.; Talchabhadel, R.; Aalto, J.; Baidya, S.K. New climatic classification of Nepal. Theor. Appl. Climatol. 2015, 125, 799-808. [CrossRef]

64. Hannah, D.M.; Kansakar, S.L.; Gerrard, A.J.; Rees, G. Flow regimes of Himalayan rivers of Nepal: Nature and spatial patterns. J. Hydrol. 2005, 308, 18-32. [CrossRef]

65. Ichiyanagi, K.; Yamanaka, M.D.; Muraji, Y.; Vaidyad, B.K. Precipitation in Nepal between 1987 and 1996. Int. J. Climatol. 2007, 27, 1753-1762. [CrossRef]

66. Bookhagen, B.; Burbank, D.W. Towards a complete Himalayan hydrologic budget: The spatiotemporal distribution of snow melt and rainfall and their impact on river discharge. J. Geophys. Res. 2010. [CrossRef] 
67. Mimeau, L.; Esteves, M.; Zin, I.; Jacobi, H.-W.; Brun, F.; Wagnon, P.; Koirala, D.; Arnaud, Y. Quantification of different flow components in a high-altitude glacierized catchment (Dudh Koshi, Himalaya): Some cryospheric-related issues. Hydrol. Earth Syst. Sci. 2019, 23, 3969-3996. [CrossRef]

68. Aili, T.; Soncini, A.; Bianchi, A.; Diolaiuti, G.; D’Agata, C.; Bocchiola, D. Assessing water resources under climate change in high-altitude catchments: A methodology and an application in the Italian Alps. Theor. Appl. Climatol. 2018, 1-22. [CrossRef]

69. Rosso, R. Nash model relation to Horton order ratios. Water Resour. Res. 1984, 20, 914-920. [CrossRef]

70. Vuillermoz, E.; Senese, A.; Diolaiuti, G.A.; Smiraglia, C.; Cristofanelli, P.; Marinoni, A.; Verza, G.P.; Bonasoni, P. The Case Study of the Changri Nup Glacier (Nepal, Himalaya) to Understand Atmospheric Dynamics and Ongoing Cryosphere Variations. Eng. Geol. Soc. Territ. 2014, 1, 73-76.

71. Senese, A.; Maugeri, M.; Vuillermoz, E.; Smiraglia, C.; Diolaiuti, G. Using daily air temperature thresholds to evaluate snow melting occurrence and amount on Alpine glaciers by T-index models: The case study of the Forni Glacier (Italy). Cryosphere 2014, 8, 1921-1933. [CrossRef]

72. Martinec, J. Indirect evaluation of snow reserves in mountain basins. IAHS Publ. 1991, 205, 111-119.

73. Tandong, Y.; Jianchen, P.; Ninlian, W.; Lide, T. A new type of ice formation zone found in the Himalayas. Chin. Sci. Bull. 1999, 44, 469-474.

74. Epstein, S.; Mayeda, T. Variations of $18 \mathrm{O}$ contents of water from natural sources. Geochim. Cosmochim. Acta 1953, 4, 213-224. [CrossRef]

75. Bombelli, G.M.; Soncini, A.; Bianchi, A.; Bocchiola, D. Potentially modified hydropower production under climate change in the Italian Alps. Hydrol. Process. 2019, 33, 2355-2372. [CrossRef]

76. Tian, L.; Yao, T.; Schuster, P.F.; White, J.W.C.; Ichiyanagi, K.; Pendall, E.; Pu, J.; Yu, W. Oxygen-18 concentrations in recent precipitation and ice cores on the Tibetan Plateau. J. Geophys. Res. 2003, 108, 4293. [CrossRef]

77. Marinoni, A.; Polesello, S.; Smiraglia, C.; Valsecchi, S. Chemical composition of fresh snow samples from the southern slope of Mt. Everest region (Khumbu-Himal region, Nepal). Atmos. Environ. 2001, 35, 3183-3190. [CrossRef]

78. Shrestha, M.; Wang, L.; Koike, T.; Xue, Y.; Hirabayashi, Y. Modeling the Spatial Distribution of Snow Cover in the Dudhkoshi Region. of the Nepal Himalayas. J. Hydrometeorol. 2012, 13, 204-222. [CrossRef]

79. Brun, F.; Wagnon, P.; Berthier, E.; Shea, J.M.; Immerzeel, W.W.; Kraaijenbrink, P.D.A.; Vincent, C.; Reverchon, C.; Shrestha, D.; Arnaud, Y. Ice cliff contribution to the tongue-wide ablation of Changri Nup Glacier, Nepal, central Himalaya. Cryosphere 2018, 12, 3439-3457. [CrossRef]

80. Nicholson, L.; Benn, D.I. Calculating ice melt beneath a debris layer using meteorological data. J. Glaciol. 2006, 52, 463-470. [CrossRef]

81. Smiraglia, C.; Mayer, C.; Mihalcea, C.; Diolaiuti, G.; Belò, M.; Vassena, G. Ongoing variations of Himalayan and Karakoram glaciers as witnesses of global changes: Recent studies on selected glaciers. Dev. Earth Surf. Process. 2007, 10, 235-247.

82. Bocchiola, D.; Senese, A.; Mihalcea, C.; Mosconi, B.; D’Agata, C.; Smiraglia, C.; Diolaiuti, G. An ablation model for debris covered ice: The case study of Venerocolo Glacier (Italian Alps). Geogr. Fis. Din. Quat. 2015, 38, 113-128.

(C) 2020 by the authors. Licensee MDPI, Basel, Switzerland. This article is an open access article distributed under the terms and conditions of the Creative Commons Attribution (CC BY) license (http://creativecommons.org/licenses/by/4.0/). 